UNIVERSIDADE DE SÃO PAULO

FACULDADE DE ODONTOLOGIA DE RIBEIRÃO PRETO

FERNANDA GRILO DE AZEVEDO

ANÁLISE COMPARATIVA IN VITRO DO EFEITO DA OSTEOPOROSE NO COMPORTAMENTO DE CÉLULAS OSTEOBLÁSTICAS DA MEDULA ÓSSEA E DA CALVÁRIA DE RATAS OVARIECTOMIZADAS

RIBEIRÃO PRETO 


\section{ANÁLISE COMPARATIVA IN VITRO DO EFEITO DA OSTEOPOROSE NO COMPORTAMENTO DE CÉLULAS OSTEOBLÁSTICAS DA MEDULA ÓSSEA E DA CALVÁRIA DE RATAS OVARIECTOMIZADAS}

Dissertação apresentada à Faculdade de Odontologia de Ribeirão Preto da Universidade de São Paulo para obtenção do título de Mestre no Programa de Reabilitação Oral.

Área de concentração: Biologia Oral

Orientador: Profa. Dra. Karina Fittipaldi Bombonato Prado

RIBEIRÃO PRETO 
AUTORIZO A REPRODUÇÃO E DIVULGAÇÃO TOTAL OU PARCIAL DESTE TRABALHO, POR QUALQUER MEIO CONVENCIONAL OU ELETRÔNICO, PARA FINS DE ESTUDO E PESQUISA, DESDE QUE CITADA A FONTE.

Ficha Catalográfica

Faculdade de Odontologia de Ribeirão Preto da Universidade de São Paulo

Azevedo, Fernanda Grilo de

Análise comparativa in vitro do efeito da osteoporose no comportamento de células osteoblásticas da medula óssea e da calvária de ratas ovariectomizadas. Ribeirão Preto, 2014.

86 p. : il. ; $30 \mathrm{~cm}$

Dissertação de Mestrado apresentada à Faculdade de Odontologia de Ribeirão Preto/USP. Área de concentração: Biologia Oral.

Orientador: Bombonato-Prado, Karina Fittipaldi.

1. Osteoporose. 2. Ovariectomia. 3. Cultura de célula. 4. Osteoblasto. 5. Rato 
FOLHA DE APROVAÇÃO

Azevedo FG. Análise comparativa in vitro do efeito da osteoporose no comportamento de células osteoblásticas da medula óssea e da calvária de ratas ovariectomizadas. Dissertação apresentada à Faculdade de Odontologia de Ribeirão Preto da Universidade de São Paulo para obtenção do título de Mestre no Programa de Reabilitação Oral. Área de concentração: Biologia Oral.

Data da aprovação:

\section{Banca Examinadora:}

Prof.(a). Dr.(a).:

Instituição:

Julgamento: Assinatura:

Prof.(a). Dr.(a).:

Instituição:

Julgamento: Assinatura:

Prof.(a). Dr.(a).:

Instituição:

Julgamento: Assinatura: 
Este trabalho foi desenvolvido no Laboratório de Cultura de Células do Departamento de Morfologia, Fisiologia e Patologia Básica e no Laboratório de Biologia Molecular do Departamento de Cirurgia e Traumatologia Buco-Maxilo Facial e Periodontia da Faculdade de Odontologia de Ribeirão Preto - Universidade de São Paulo, com apoio financeiro da Fundação de Amparo à Pesquisa do Estado de São Paulo (FAPESP) sob processos 2012/13330-6 e 2012/17747-9. 
(D)dicatória 
A Deus, por iluminar e guiar meu caminho durante todos os momentos e por conceder-me força, coragem e sabedoria para enfrentar os desafios do dia-a-dia.

A minha mãe, Rosana Grilo, por todo amor, incentivo, confiança, dedicação e amizade; e ao meu pai, Carlos Alberto de Azevedo, pelo apoio e por proporcionar condições para que este momento se concretizasse.

Ao Júlio Cássio Wagner de Barros, pela amizade, carinho, apoio e auxílio em todos os momentos.

Aos meus queridos avós Fernando Lázaro Grilo (in memoriam) e Ivone D'Angelo Grilo, por serem meus grandes exemplos de vida, caráter, dedicação e amor.

Ao meu noivo Roger Rodrigo Fernandes, pelos ensinamentos, conselhos, dedicação, paciência, amizade, respeito e amor. Por tornar este momento uma época que será lembrada com muito carinho, mesmo com todos os desafios que surgiram durante esta caminhada! Muito obrigada! 


\section{Algradecimentos Especiais}


A minha orientadora Profa. Dra. Karina Fittipaldi Bombonato Prado, por toda a educação, respeito, confiança e dedicação para que este trabalho acontecesse. Pela paciência infinita, estando sempre disposta a me ajudar. Por compartilhar conhecimento e experiências que contribuíram para meu crescimento pessoal e profissional.

Ao amigo Luiz Gustavo de Sousa, por toda a dedicação e manejo dos animais utilizados nesta pesquisa, sem os quais não seria possível a realização deste trabalho. Pela paciência e por tudo o que me foi ensinado, muito obrigada! 
Algradecimentos 
À Faculdade de Odontologia de Ribeirão Preto da Universidade de São Paulo, representada pelo Diretor Prof. Dr. Valdemar Mallet da Rocha Barros e pela ViceDiretora Profa. Dra. Léa Assed Bezerra da Silva.

À Coordenação Geral da Pós-Graduação da Faculdade de Odontologia de Ribeirão Preto da Universidade de São Paulo, representada pelo Prof. Dr. Arthur Belém Novaes Júnior.

À Coordenação do Programa de Pós Graduação em Reabilitação Oral, na pessoa da Profa. Dra. Fernanda de Carvalho Panzeri Pires de Souza e ViceCoordenadora Profa. Dra. Helena de Freitas Oliveira Paranhos e a todos os docentes do Programa.

Ao Departamento de Morfologia, Fisiologia e Patologia Básica da Faculdade de Odontologia de Ribeirão Preto da Universidade de São Paulo e seus funcionários e docentes, representados pelo Prof. Dr. José Moacir Marin.

Ao Departamento de Cirurgia Buco-Maxilo Facial e Periodontia da Faculdade de Odontologia de Ribeirão Preto da Universidade de São Paulo e seus respectivos funcionários e docentes, na pessoa do Prof. Dr. Mario Taba Júnior.

Aos professores Dr. Adalberto Luiz Rosa, Dr. Márcio Mateus Beloti, Dr. Paulo Tambasco de Oliveira e Dra. Selma Siéssere pela paciência, incentivo, ensinamentos e importantes contribuições na realização desse trabalho.

Ao Prof. Dr. Jorge Esquiche León, pela amizade, incentivo e solicitude desde a Graduação.

Aos funcionários Adriana Luisa Gonçalves de Almeida, Christopher Carvalho, Fabíola Singaretti de Oliveira e Milla Sprone Tavares, pela disposição e auxílio prestado durante a realização deste trabalho.

Aos companheiros do Laboratório de Cultura de Células: Daniela Thomazatti Chimello de Souza, Emanuela Prado Ferraz, Gabriela Caroline Alonso, Gabriela 
Cerminaro Rodrigues, Gileade Pereira Freitas, Helena Bacha Lopes, Larissa Moreira Spínola de Castro Raucci, Larissa Sverzut Bellesini, Leonardo Pimentel, Lucas Novaes Teixeira, Maidy Rehder Wimmers Ferreira, Marcelo Francischini, Mayara Sgarbi Semeghini, Natalia Manrique Cursino, Renan de Barros e Lima Bueno, Rodrigo Paolo Flores Abuna, Rogério Bentes Kato, Thiago de Santana Santos pela amizade, colaboração, companhia e auxílio durante todo o trabalho e por todos os alegres momentos vividos.

À Angélica Emanuela dos Santos Pires, Fabiana de Almeida Curylofo, Lílian Márlia Aparecida Carvalho e Priscilla Hakime Scalize, amigas de todas as horas, que sempre estiveram ao meu lado me apoiando e alegrando meus dias.

À Isabel Cristina Galino Sola, Mary Possano Carmessano e Regiane Cristina Moi Sacilotto, secretárias da Seção de Pós-Graduação da Faculdade de Odontologia de Ribeirão Preto da Universidade de São Paulo.

À Fernanda Talita de Freitas e Regiane Tirado Damasceno, secretárias do Programa de Pós-Graduação em Reabilitação Oral da Faculdade de Odontologia de Ribeirão Preto da Universidade de São Paulo.

À Clélia Aparecida Celino, secretária do Departamento de Morfologia, Fisiologia e Patologia Básica da Faculdade de Odontologia de Ribeirão Preto da Universidade de São Paulo.

Aos professores e funcionários da Faculdade de Odontologia de Ribeirão Preto da Universidade de São Paulo.

À Fundação de Amparo à Pesquisa do Estado de São Paulo (FAPESP), pelo auxílio financeiro ao trabalho e pela concessão da bolsa de mestrado.

À todos que, direta ou indiretamente, contribuíram para a realização deste trabalho. 
Resumo 


\section{RESUMO}

\section{AZEVEDO FG. Análise comparativa in vitro do efeito da osteoporose no} comportamento de células osteoblásticas da medula óssea e da calvária de ratas ovariectomizadas [dissertação]. Ribeirão Preto: Universidade de São Paulo, Faculdade de Odontologia de Ribeirão Preto, 2014. 86p.

A osteoporose, uma doença óssea progressiva, é considerada um grave problema de saúde pública, sendo uma das condições mais importantes associadas ao envelhecimento e que afeta milhões de pessoas no mundo. Esta doença multifatorial é caracterizada pela densidade óssea reduzida e deterioração da microarquitetura óssea. O objetivo deste trabalho foi investigar as mudanças comportamentais em células mesenquimais da medula óssea e células osteoblásticas da calvária de ratas induzidas à osteoporose. Após aprovação da Comissão de Ética no Uso de Animais, 18 ratas Wistar foram utilizadas e divididas em grupos controle e ovariectomizadas. Após 150 dias, as ratas de ambos os grupos foram sacrificadas para coleta dos fêmures e fragmentos da calvária. As células recolhidas a partir da medula óssea e calvária foram cultivadas em placas de 24 poços $(n=5)$ para avaliação da proliferação e viabilidade celular, atividade de fosfatase alcalina (ALP), detecção e quantificação de nódulos mineralizados e análise da expressão gênica por meio de PCR em tempo real. Os dados foram submetidos ao testes de Kruskal-Wallis e Mann-Whitney, com nível de significância de 5\%. As células da medula óssea do grupo controle (MC) mostraram uma diminuição significativa na proliferação quando comparado com as células do grupo controle da calvária (CC) em todos os períodos $(p<0,05)$. Por outro lado, as células da medula óssea de ratas com osteoporose 
(MO) revelaram um aumento significativo na taxa de proliferação após 7 e 10 dias ( $p$ $<0,01)$ em comparação às células da calvária de ratas ovariectomizadas $(\mathrm{CO})$. A viabilidade celular foi maior em todos os períodos estudados dos grupos CC e CO em relação aos grupos $\mathrm{MC}$ e $\mathrm{MO}(\mathrm{p}<0,05)$. A atividade de fosfatase alcalina não foi significativamente diferente após 7 dias de cultura entre os grupos estudados; por outro lado, após 10 e 14 dias, observou-se uma diminuição da sua atividade no grupo MC quando comparado ao grupo CC $(p<0,01)$. Nas ratas com osteoporose, as células da medula óssea mostraram um aumento desta atividade quando comparada às células de calvária $(p<0,01)$. A análise dos nódulos mineralizados após 14 e 21 dias revelou que os grupos controle CC e MC não apresentaram diferenças significativas, ao passo que no grupo MO observou-se um aumento da mineralização quando comparado ao grupo $\mathrm{CO}$ nos mesmos períodos experimentais. Os resultados obtidos na análise de expressão gênica mostraram que para os genes Runx2, Oc, Alpl, Rank-I e Era a expressão no grupo MO foi maior que no grupo $M C(p<0,05)$, enquanto que para as células da calvária, $C C$ teve maior expressão gênica que $C O(p<0,05)$. Os genes Opg e $\operatorname{Er} \beta$ apresentaram variações de acordo com o grupo avaliado. Frente aos resultados obtidos, sugere-se que existam alterações no metabolismo das células progenitoras e células diferenciadas após a indução da osteoporose e que as células da medula óssea apresentam um aumento da sua função como uma resposta compensatória neste modelo animal ovariectomizado.

Palavras-Chave: Osteoporose. Ovariectomia. Cultura de células. Osteoblasto. Rato 
Albstract 


\section{ABSTRACT}

AZEVEDO FG. Comparative analysis of the effect of osteoporosis on the in vitro behavior of bone marrow and calvaria osteoblastic cells from female ovariectomized rats [thesis]. Ribeirão Preto: University of São Paulo, School of Dentistry of Ribeirão Preto, 2014. 86p.

Osteoporosis, a progressive bone disease, is considered a serious public health problem, being one of the most important conditions associated with aging, affecting millions of people worldwide. This multifactorial disease is characterized by reduced bone density and deterioration of bone microarchitecture. The objective of this work was to investigate the behavioral changes in mesenchymal cells from bone marrow and osteoblastic cells from calvaria bone of female rats induced to osteoporosis. After institutional review board approval, 18 Wistar female rats were used and divided into control and ovariectomized groups. After 150 days, the rats of both groups were sacrificed for collection of femurs and calvariae fragments. The cells collected from bone marrow and calvaria were cultured in 24-well plates $(n=5)$ for the assessment of cell proliferation and viability, alkaline phosphatase (ALP) activity and detection and quantification of mineralized nodules. The data were submitted to Kruskal-Wallis and Mann-Whitney tests, with significance level set at $5 \%$. The cells from bone marrow control group (MC) showed a significantly decrease in proliferation when compared to the cells from calvaria bone control group (CC) in all periods evaluated $(p<0,05)$. On the other hand, bone marrow cells from osteoporotic rats (MO) revealed a significant increase in their proliferation rate after 7 and 10 days $(\mathrm{p}<$ $0,01)$ compared to calvaria cells from ovariectomized rats $(\mathrm{CO})$. Cell viability was higher in all investigated periods of $\mathrm{CC}$ and $\mathrm{CO}$ groups compared to $\mathrm{MC}$ and $\mathrm{MO}$ groups $(p<0,05)$. Alkaline phosphatase activity was not significantly different after 7 days of culture among the studied groups; in spite of that, after 10 and 14 days, there was a decrease in its activity in MC group when compared to $C C(p<0,01)$. In the osteoporotic rats, bone marrow cells showed an increase in this activity when compared to calvaria cells $(p<0,01)$. The analysis of mineralized nodules after 14 and 21 days revealed that control groups (CC and $M C)$ did not have significant 
differences, whereas it was observed in MO group an increase in the mineralization when compared to $\mathrm{CO}$ in the same experimental periods. The data obtained in the analysis of gene expression showed that for Runx2, Oc, Alpl, Rank-I and Era genes, the expression in $M O$ group was higher than in $M C(p<0,05)$, whereas for the calvaria cells, CC group had higher gene expression than $C O$ group $(p<0,05)$. The Opg and $\operatorname{Er} \beta$ genes showed variations according to the evaluated group. Thus, it is suggested that there are changes in the metabolism of progenitor and differentiated cells after osteoporosis induction and that bone marrow cells present an enhancement of their function as a compensatory response in this ovariectomized rat model.

Keywords: Osteoporosis. Ovariectomy. Cell culture. Osteoblast. Rat model. 
Qumário 


\section{SUMÁRIO}

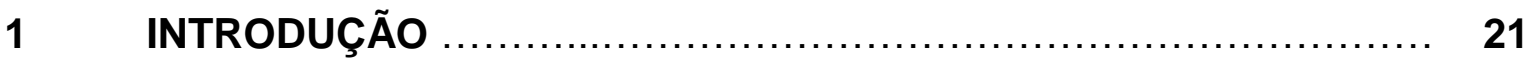

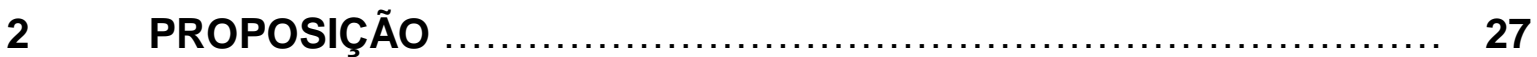

$2.1 \quad$ Objetivos gerais ........................................................ 27

2.2 Objetivos específicos ................................................. 27

$3 \quad$ MATERIAL E MÉTODOS ........................................... 29

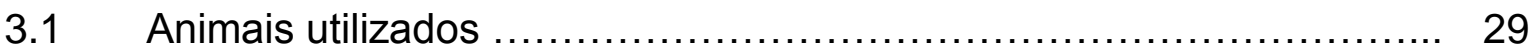

3.1.1 Grupo ovariectomizado - Indução da osteoporose ............................. 29

3.1.2 Grupo controle - Sham ......................................... 34

3.2 Eutanásia dos animais e coleta de material ...................................... 34

3.2.1 Cultura de células mesenquimais da medula óssea de ratas .............. 35

3.2.2 Cultura de células da calvária de ratas ............................................. 36

3.3 Ensaios bioquímicos ................................................. 37

3.3.1 Proliferação celular ................................................... 37

3.3.2 Viabilidade celular ................................................... 38

3.3.3 Conteúdo de proteína total e atividade de fosfatase alcalina (ALP) ..... 38

3.3.4 Formação e quantificação de matriz mineralizada .............................. 40

3.4 Análise da expressão gênica por reação em cadeia de polimerase em tempo real (Real-time PCR) ........................................................ 40

$3.5 \quad$ Análise estatística .................................................................... 43

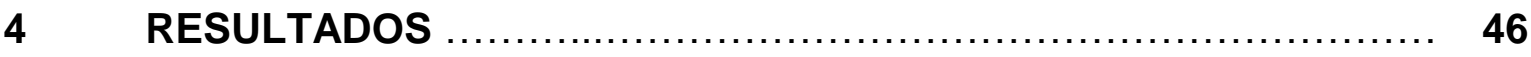

$4.1 \quad$ Proliferação celular ....................................................... 46

$4.2 \quad$ Viabilidade celular ...................................................... 47

4.3 Atividade de fosfatase alcalina (ALP) ………............................. 48

4.4 Quantificação dos nódulos de mineralização ...................................... 49

4.5 Expressão gênica por reação em cadeia de polimerase em tempo real (Real-time PCR) ..................................................................... 51

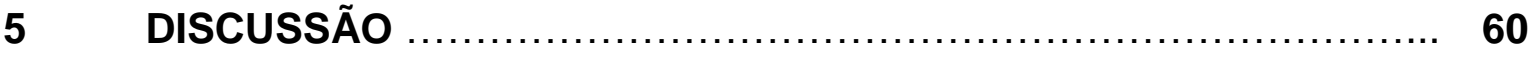

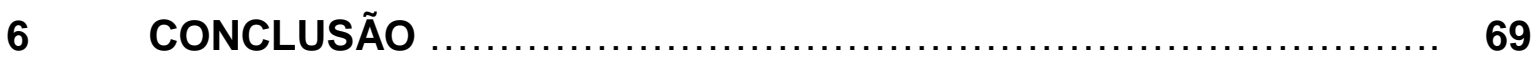

7 REFERÊNCIAS BIBLIOGRÁFICAS ........................................... 71

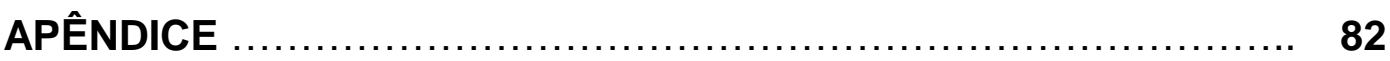

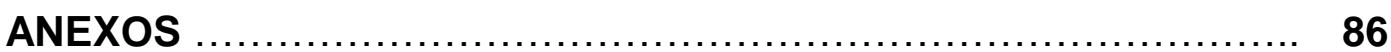


बntroducẫ 


\section{INTRODUÇÃO}

Ao longo da vida o organismo passa por processos de formação e remodelação óssea. Para que isto ocorra, deve haver uma sincronia entre as células responsáveis por estas funções: os osteoblastos e osteoclastos. Os osteoclastos são células gigantes, multinucleadas, localizadas na superfície do osso e com capacidade para reabsorvê-lo. O osso reabsorvido será substituído por uma matriz óssea jovem, produzida pelos osteoblastos, que são células mesenquimais originárias da medula óssea. Tal processo, conhecido por remodelação óssea, é fisiológico e mantém a integridade do esqueleto (Marie e Kassem, 2011; Sapir-Koren e Livshits, 2013).

Sabe-se que o grau de mineralização é influenciado pelas taxas de remodelação óssea e deposição mineral. O desequilíbrio nesse processo pode gerar uma desordem sistêmica crônica conhecida por osteoporose, onde os ossos tornamse menos resistentes, apresentando amplos canais de reabsorção. Essa condição patológica decorre da diminuição na formação óssea, do aumento na reabsorção do osso formado ou da combinação de ambos (Amadei et al., 2006).

Fatores genéticos, nutricionais e comportamentais são de fundamental importância na etiologia desta doença (Raisz, 2005). Segundo critérios da Organização Mundial da Saúde - OMS, aproximadamente um terço das mulheres de raça branca, com idade superior aos 65 anos, tem osteoporose (Oliveira, 2002). Embora seja uma condição predominante em mulheres, mais de $20 \%$ das fraturas vertebrais e $30 \%$ das fraturas de quadril ocorrem em homens, associada com maior mortalidade dos mesmos (Ruiz-Gaspà et al., 2010). Hábitos dietéticos como baixo consumo de cálcio e vitaminas, abuso de álcool e tabaco, estilo de vida sedentário e 
o uso crônico de glicocorticóides para tratamento de doenças sistêmicas também são considerados fatores de risco desta patologia (Downey e Siegel, 2006; Sandhu e Hampson, 2011).

Embora a osteoporose seja uma doença de etiologia multifatorial, a deficiência de estrógeno após a menopausa é a causa mais comum do surgimento da osteoporose em mulheres (Becker, 2008), que atinge uma em cada quatro na menopausa e, após os 65 anos, uma em cada três. Essas mulheres chegam a perder de 40 a 50\% da massa óssea até o final da vida (Amadei et al., 2006).

A osteoporose pós-menopausa foi descrita pela primeira vez em 1940 pelo endocrinologista Fuller Albright, que a definiu como uma condição de formação óssea prejudicada devido à deficiência de estrógeno (Albright, Bloomberg e Smith, 1940), uma vez que este hormônio regula a remodelação óssea por modular a produção de citocinas e fatores de crescimento a partir da medula e células ósseas (Pacifici, 1996). De fato, segundo Simon (2007), células ósseas como os osteoblastos e osteoclastos estão sob o controle de hormônios sistêmicos e citocinas; a deficiência de estrógeno afeta os níveis de citocinas específicas que circulam no organismo, aumentando sua concentração, o que favorece a reabsorção óssea por aumentar o recrutamento, a diferenciação e a ativação de células osteoclásticas (Horowitz, 1993; Manolagas e Jilka, 1995).

Um modelo para osteoporose que tem sido bastante utilizado é o de ratas ovariectomizadas bilateralmente. Tal fato é comprovado na literatura e, de acordo com Frost e Jee (1992), as ratas proporcionam um modelo de estudo muito útil de osteopenia e de alguns outros problemas esqueléticos humanos importantes, pois há uma resposta similar entre ratas e humanos quanto às influências mecânicas, hormonais e medicamentosas. Um estudo realizado em tíbia de ratas mostrou que, 
cinco semanas após ovariectomização bilateral, houve perda óssea e aceleração do metabolismo esquelético (Wronski et al., 1985). Do mesmo modo, Rawlinson et al. (2009) observaram que cinco meses após a ovariectomização bilateral, ratas Sprague-Dawley apresentaram redução na densidade de mineralização no osso alveolar da mandíbula, na maxila e nos ossos parietais e frontal.

Atualmente, células mesenquimais de diversas origens são consideradas fontes para substituição de tecidos; estas células tem o potencial osteogênico e podem ser elegíveis para o reparo e manutenção do tecido ósseo, sendo muito atrativas para a engenharia tecidual. Entretanto, mudanças no seu comportamento podem ser causadas por fatores como a osteoporose, afetando a sua habilidade de autorrenovação e diferenciação (Veronesi et al., 2011).

Estudos demonstram que a deficiência de estrógeno pós-menopausa pode estimular a produção de vários fatores parácrinos pelos osteoblastos, como IL-1, IL6 e TNF- $\alpha$, os quais estão envolvidos na osteoclastogênese (Maruotti et al., 2012), aumentando a reabsorção óssea. Além disso, evidências sugerem um importante papel da RANKL (receptor activator of nuclear factor kappa B ligand), uma citocina produzida pelos osteoblastos, no metabolismo dos osteoclastos, estimulando a sua maturação e a reabsorção óssea (Dempster et al., 2012). Na osteoporose causada por deficiência de estrógeno, a ação da RANKL pode ser inibida pela osteoprotegerina (OPG), uma proteína solúvel que se liga à RANKL, impedindo a sua ligação com o osteoclasto, consequentemente inibindo a reabsorção óssea (Simonet et al., 1997).

A osteoporose não é uma condição que acomete somente o sexo feminino e vários estudos observaram alterações provocadas por esta doença no sexo masculino. Ruiz-Gaspà et al. (2010) utilizaram culturas de células osteoblásticas 
extraídas do osso alveolar de pacientes com e sem osteoporose para avaliar a proliferação destas células e a expressão gênica da osteocalcina (OC) e colágeno (COL1A1) em condições basais e com adição de vitamina $D_{3}$. Os resultados obtidos mostraram uma proliferação celular menor e mais lenta no grupo osteoporótico comparado ao controle. Além disso, os níveis de expressão dos genes relacionados ao depósito de cálcio e mineralização da matriz no grupo osteoporótico também se mostraram menores, incluindo o grupo que recebeu a vitamina. Com esses dados eles presumem que os osteoblastos de pacientes com osteoporose apresentam algum defeito intrínseco, o que prejudicaria sua função no tecido ósseo in vivo, ao contrário do que ocorre com mulheres osteoporóticas, onde a perda de densidade óssea é predominantemente devido ao aumento da reabsorção óssea.

Uma investigação realizada por D'Amelio et al. (2011) na cabeça do fêmur e na medula óssea de mulheres com fragilidade óssea demonstrou que células da medula são responsáveis pela produção de citocinas associadas à osteoclastogênese como a RANKL, enquanto que inibidores osteoblásticos como SOST e DKK-1 são produzidos principalmente por células ósseas, sugerindo uma relação íntima das duas regiões na regulação do metabolismo ósseo.

No estudo realizado por Benisch et al. (2012), foi avaliado o comportamento das células tronco mesenquimais a fim de descobrir se havia uma relação direta com a patofisiologia da osteoporose. Tais células foram obtidas do fêmur de pacientes idosos osteoporóticos e não-osteoporóticos durante cirurgia de quadril e isoladas através de cultura de células para análises de microarray e expressão gênica por meio de PCR em tempo real. Os pesquisadores notaram alterações intrínsecas no perfil das células de indivíduos com osteoporose, que apresentaram uma transcrição aumentada de inibidores da sinalização de WNT e BMP, o que leva às deficiências 
funcionais tais como inibição de diferenciação osteogênica e perda da capacidade de autorrenovação. Dessa forma, o estudo mostrou que o desequilíbrio na homeostase das células mesenquimais é tão importante quanto a reabsorção óssea aumentada em pacientes osteoporóticos.

Li et al. (2013) estudaram a diferenciação osteoblástica em animais ovariectomizados e perceberam que os osteoblastos dos animais tratados com naringina apresentaram melhor resposta à osteoporose que aqueles não tratados, reforçando assim, o prejuízo que esta patologia óssea provoca no funcionamento dos tecidos mineralizados.

Existem poucos trabalhos na literatura indicando as modificações que a osteoporose pode provocar em células osteoblásticas e suas células progenitoras. Sendo assim, a hipótese deste trabalho é a de que em condição de osteoporose, não só as células diferenciadas, mas também aquelas ainda presentes na medula óssea possam apresentar alterações metabólicas, influenciando a formação adequada de tecido ósseo. 


\section{PROPOSIÇÃO}

\subsection{Objetivo geral}

O principal objetivo deste estudo foi avaliar as diferenças comportamentais de células osteoblásticas provenientes da medula óssea e da calvária de ratas induzidas à condição de osteoporose por meio de ensaios bioquímicos e de expressão gênica quantitativa.

\subsection{Objetivos específicos}

- Avaliação da proliferação e viabilidade celular

- Atividade de fosfatase alcalina

- Detecção e quantificação de nódulos mineralizados

- Análise da expressão gênica quantitativa de genes associados à osteogênese por meio de Real-time PCR 
Chaterial e Crétodos 


\section{MATERIAL E MÉTODOS}

\subsection{Animais utilizados}

Para a realização do trabalho, fez-se necessária a aprovação da pesquisa pelo Comitê de Ética de Uso de Animais (CEUA) desta Universidade (protocolo 12.1.1286.56.0).

Todos os experimentos foram realizados em triplicata, assim, utilizou-se 18 ratas Wistar, sendo nove para o grupo controle e nove para o grupo ovariectomizado. Os animais pesavam aproximadamente $300 \mathrm{~g}$ e eram procedentes do Biotério Central do Campus da USP de Ribeirão Preto. Mantiveram-se três animais por caixa de polietileno, com temperatura ambiente controlada entre $23^{\circ} \mathrm{C} \mathrm{e}$ $24{ }^{\circ} \mathrm{C}$, com timer programado para 12 horas de iluminação diária. Os animais receberam ração e água "ad libitum" e a limpeza de suas caixas com troca da maravalha foi realizada três vezes por semana.

\subsubsection{Grupo ovariectomizado - Indução da osteoporose}

Para a indução da osteoporose, os animais foram ovariectomizados bilateralmente. Após a pesagem, as ratas foram anestesiadas, via intramuscular, com a solução anestésica de xilazina (Dopaser, Hertape Calier S.A., Juatuba, MG, Brasil) e cetamina (Ketamina Agener, Agener União, Embu-Guaçu, SP, Brasil) na proporção de $75 \mathrm{mg} / \mathrm{Kg}$ de cetamina e $10 \mathrm{mg} / \mathrm{Kg}$ de xilazina. Foi realizada a tricotomia das regiões laterais do abdômen e assepsia com álcool iodado nos locais da incisão. Durante a cirurgia, uma gaze estéril embebida em soro fisiológico a 0,9\% foi colocada sobre os olhos dos animais com o objetivo de prevenir o ressecamento das córneas. 
Incisões cutâneas bilaterais foram realizadas, sendo o tecido muscular divulsionado para a exposição dos ovários e excisão dos mesmos (Figuras 1 e 2), como descrito por Kalu (1991). Os tecidos foram suturados com fio de seda 4.0 (Ethicon, Johnson \& Johnson, São José dos Campos, SP, Brasil) de modo a fechar devidamente as margens do retalho (Figura 3). Em seguida, cada animal recebeu, via intramuscular, dose única de 24.000Ul/Kg do antibiótico penicilina (Pentabiotic Veterinário Pequeno Porte - Fort Dodge, Campinas, SP, Brasil) e uma dose de 1,1 $\mathrm{mg} / \mathrm{Kg}$ de anti-inflamatório e analgésico flunixina meglumina (Banamine Pet Injetável, Schering-Plough Coopers Brasil, São Paulo, SP, Brasil).

Os animais operados permaneceram na caixa de polietileno, em observação constante, durante 150 dias.

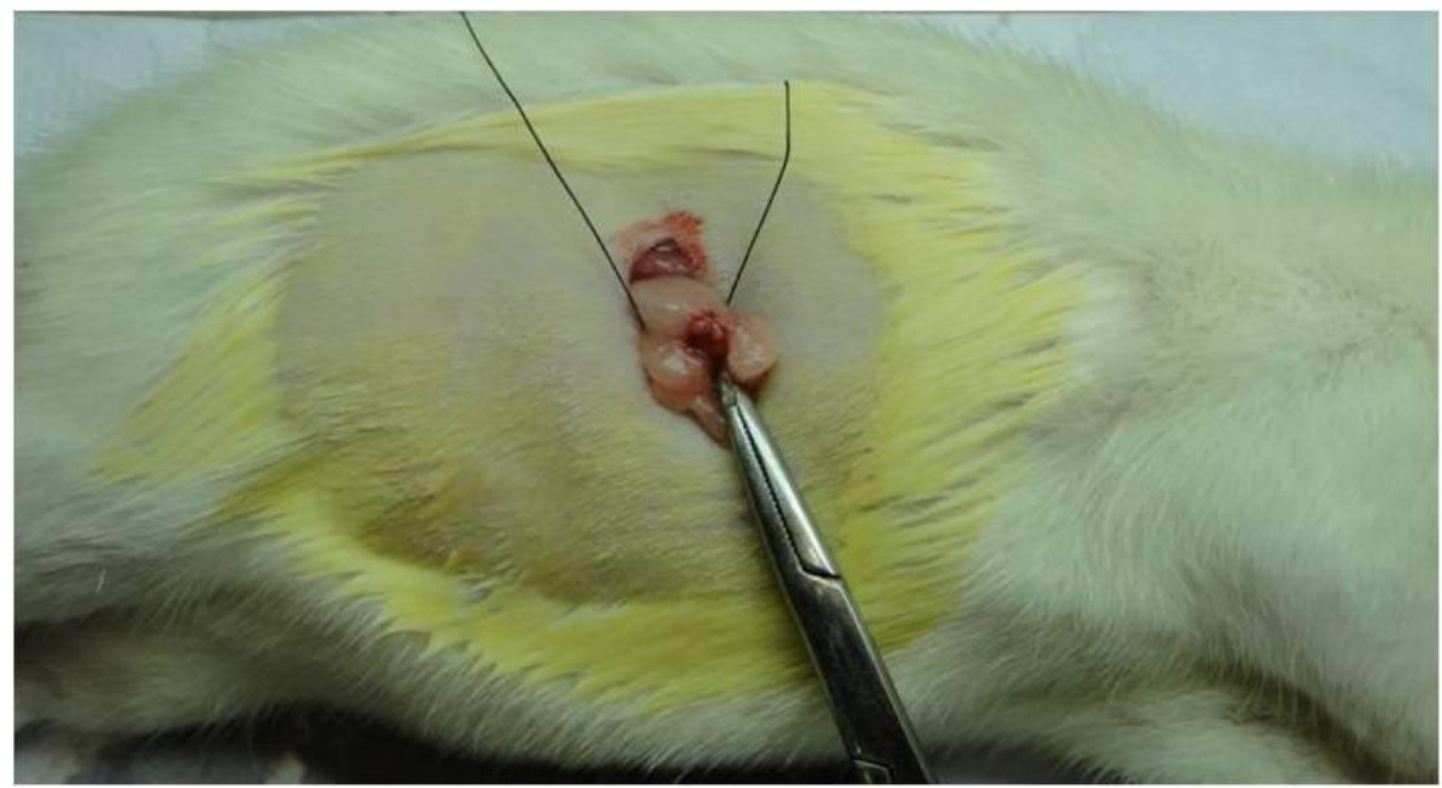

Figura 1 - Exposição do ovário e pinçamento para hemostasia antes da remoção do órgão. Este procedimento foi realizado bilateralmente. 


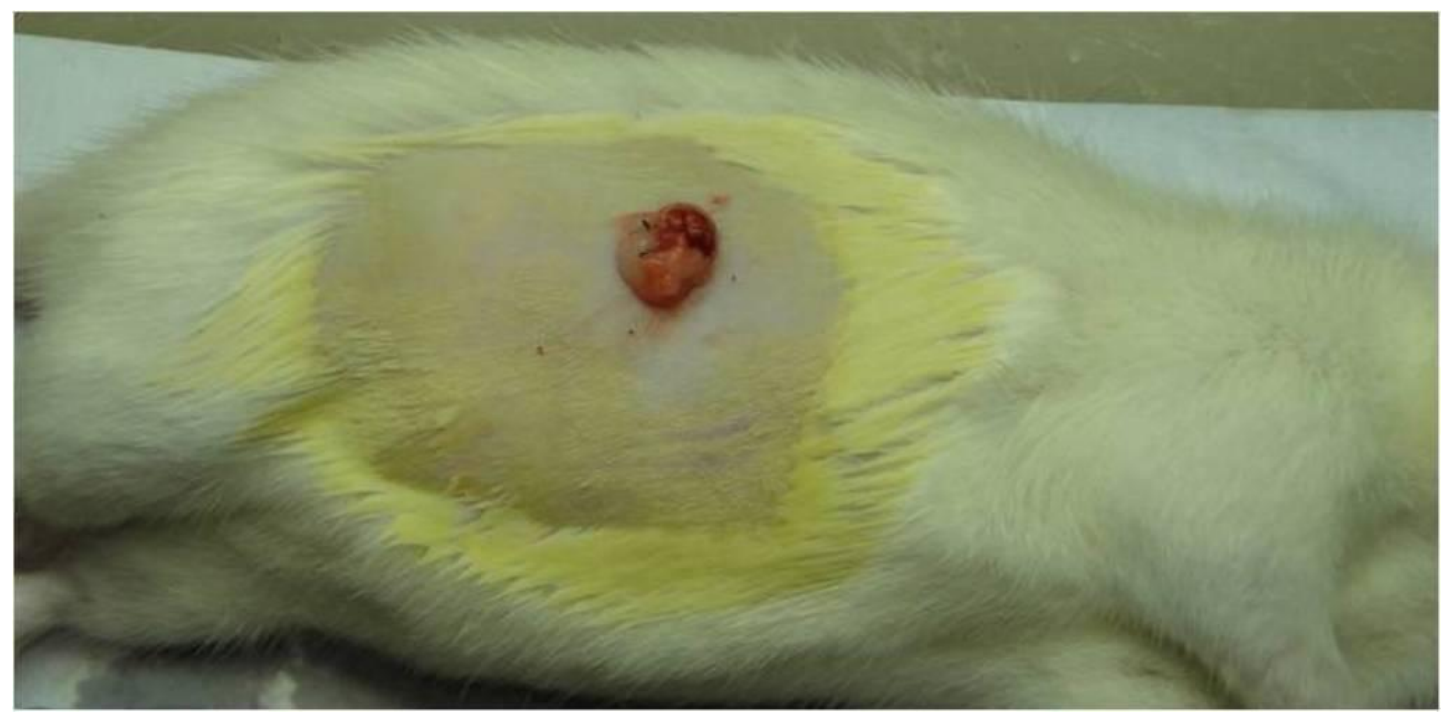

Figura 2 - Ovário removido.

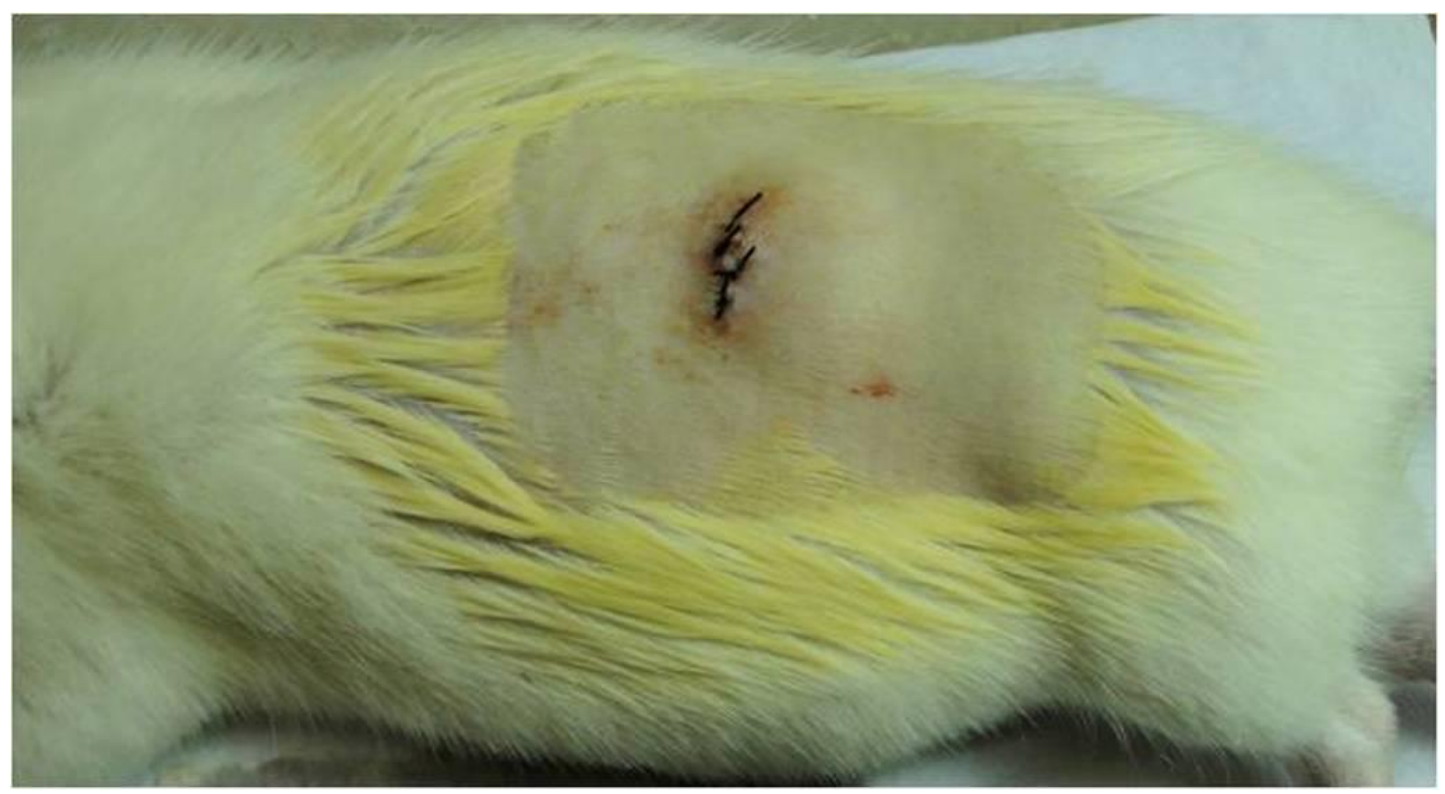

Figura 3 - Aspecto da sutura após ovariectomia.

Duas semanas após a cirurgia, os animais foram submetidos ao exame do ciclo estral, por meio da coleta de líquido vaginal por um período de 5 dias consecutivos. Para o desenvolvimento desta técnica foi introduzido, com o auxílio de uma borracha de conta-gotas acoplada a uma ponteira pequena, uma dose de 
solução salina (cerca de $1 \mathrm{~mL}$ ) no interior da vagina da rata. Após a introdução, a solução foi rapidamente aspirada e seu conteúdo transferido para uma lâmina de vidro e imediatamente observado em microscopia óptica. Este procedimento foi realizado no início da manhã (Figura 4).
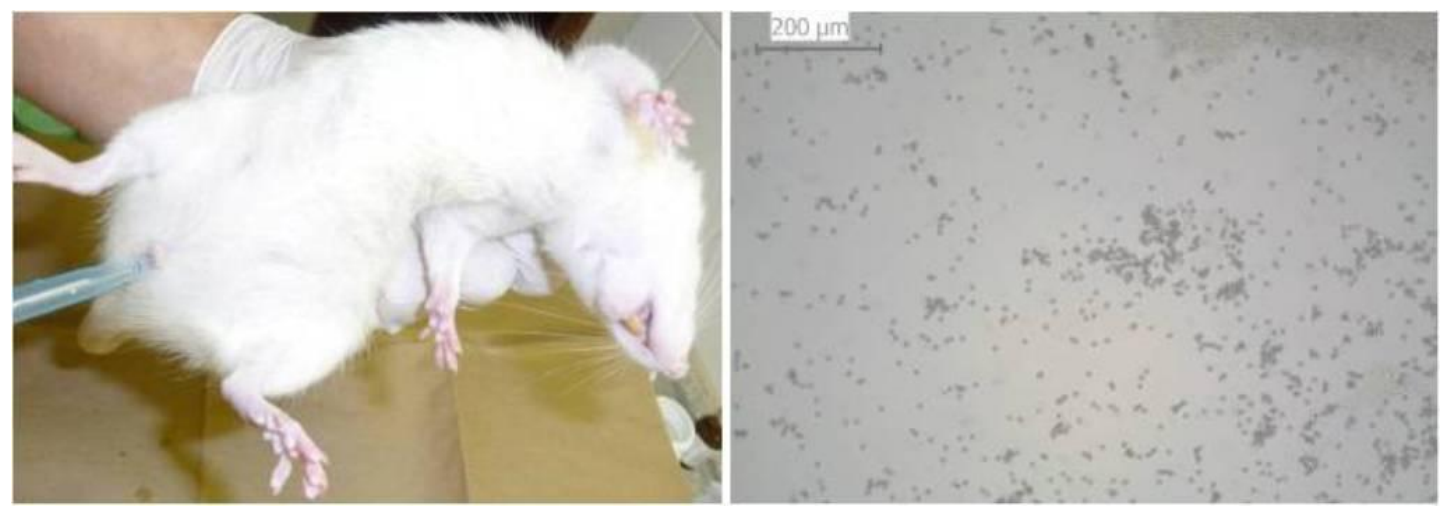

Figura 4 - À esquerda, coleta do fluido vaginal de rata ovariectomizada. À direita, fotomicrografia do fluido vaginal não corado, com predominância de leucócitos, caracterizando a fase diestro do ciclo estral.

A literatura mostra que esta técnica é ideal para investigar as mudanças ocorridas no ciclo reprodutivo. O período do ciclo estral das ratas dura de 4 a 5 dias. Este ciclo pode ser dividido em quatro fases: metaestro, diestro, proestro e estro. Cada uma das fases se caracteriza por apresentar um tipo de célula predominante que pode ser facilmente observado nos esfregaços da vagina, assim como o nível de hormônios sexuais presentes no animal. Na fase metaestro, observam-se leucócitos e algumas células epiteliais anucleadas remanescentes. Nesta fase iniciase o aumento da secreção de estrógeno e o primeiro pico de progesterona. Na fase diestro observam-se basicamente leucócitos e algumas células epiteliais nucleadas, sendo marcado pelo final do primeiro pico de progesterona e baixos níveis de 
estrógeno. Na terceira fase, proestro, o número de células epiteliais nucleadas aumenta enquanto os leucócitos praticamente desaparecem, ocorrendo neste momento o pico de secreção de estrógeno e o segundo pico de progesterona, enquanto na fase estro são visualizadas basicamente células epiteliais queratinizadas da camada córnea e o nível de estrógeno retorna aos valores basais (Hoar e Hickman, 1975; Marcondes et al., 2002). Sendo assim, os animais que foram submetidos à ovariectomia permaneceram sempre na fase diestro, enquanto que nos animais do grupo controle, não houve qualquer alteração no seu ciclo estral.

Durante o processo de sacrifício dos animais, foi avaliado, também, o efeito da ovariectomia, por meio do exame macroscópico dos cornos uterinos (Figura 5). Para a realização desta análise fez-se necessário, antes do sacrifício dos animais, incisionar a região abdominal para localização das respectivas estruturas. Nos animais ovariectomizados os cornos uterinos apresentaram-se finos, atróficos e anêmicos.
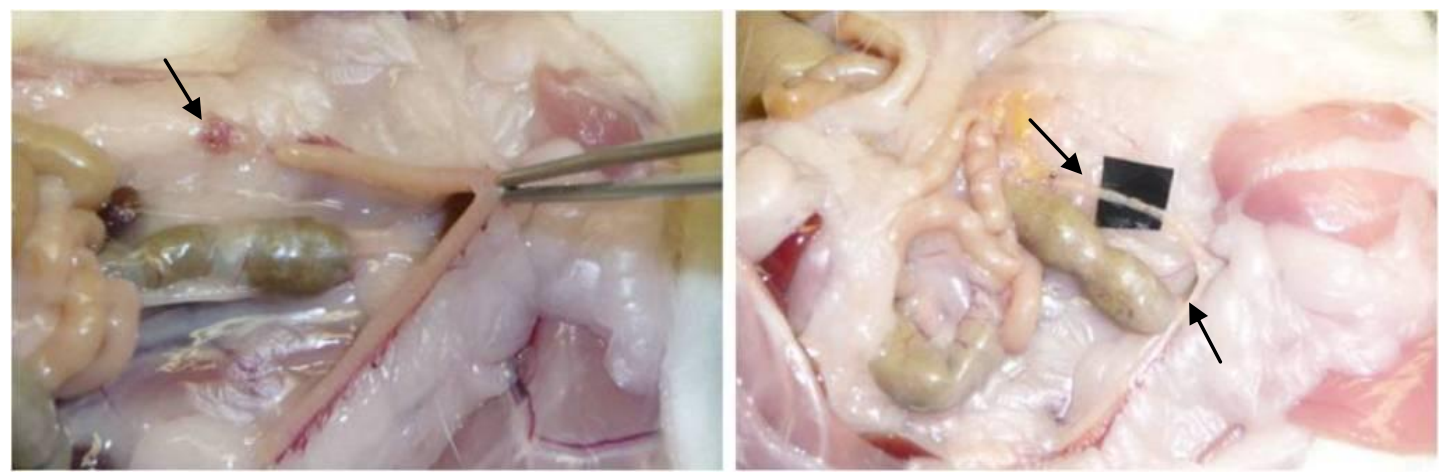

Figura 5 - Na foto à esquerda, cornos uterinos de aspecto normal, com presença de ovário, apontado pela seta. À direita, cornos uterinos atrofiados, confirmando o sucesso da ovariectomia. 


\subsubsection{Grupo controle - Sham}

Os animais do grupo controle foram submetidos apenas ao estresse da cirurgia, tendo os ovários expostos ao ambiente e recolocados, em seguida, no interior do abdômen (Figura 6). Assim como os animais do grupo ovariectomizado, estes foram anestesiados antes do procedimento cirúrgico e medicados, após a cirurgia, com dose única de $24.000 \mathrm{Ul} / \mathrm{Kg}$ de penicilina (Fort Dodge), via intramuscular, e uma dose de $1,1 \mathrm{mg} / \mathrm{Kg}$ de flunixina meglumina (Schering-Plough Coopers Brasil), sendo observados, rotineiramente, por 150 dias.

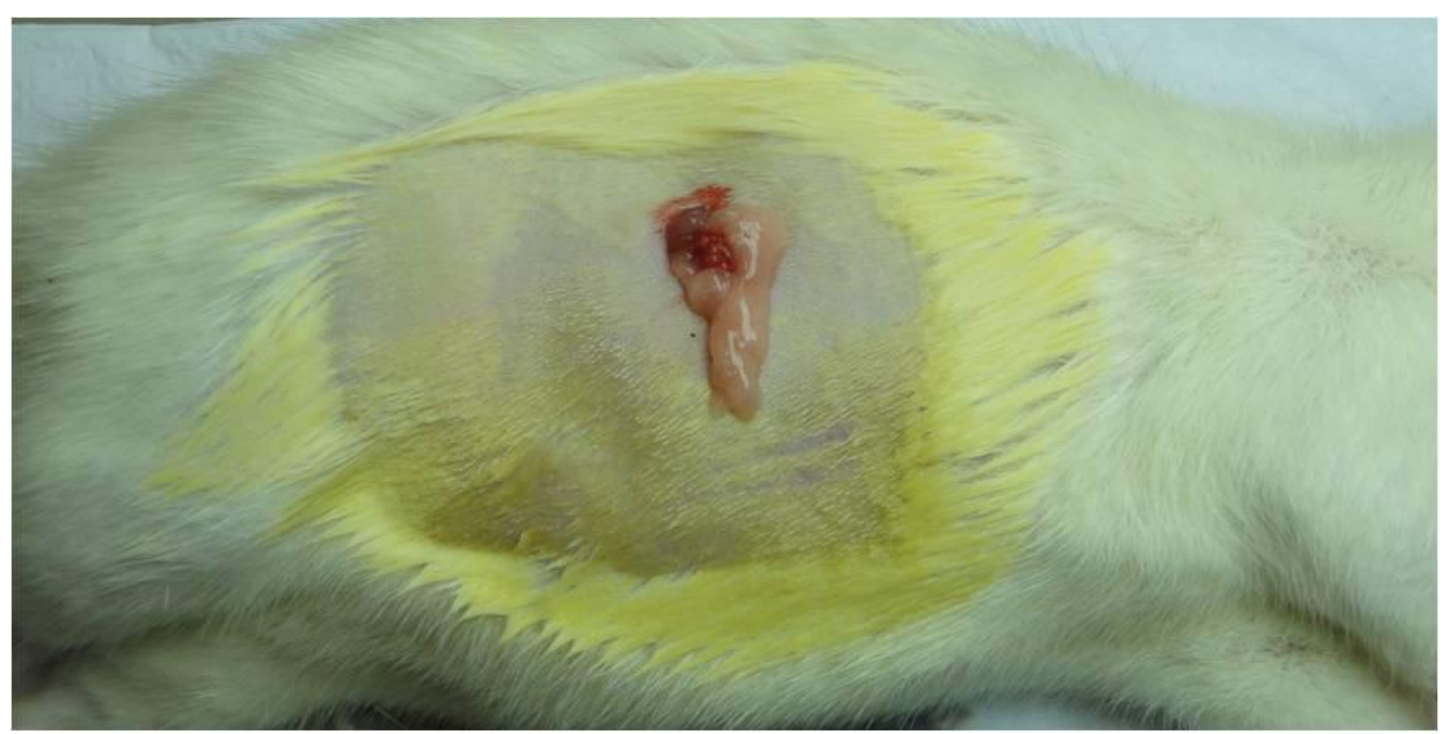

Figura 6 - Cirurgia do grupo "sham" com exposição do ovário e recolocação no interior do abdômen.

\subsection{Eutanásia dos animais e coleta de material}

As ratas foram eutanasiadas com sobredose de anestésico cetamina e xilazina após 150 dias da cirurgia de ovariectomia; a coleta dos fêmures e da calvária foi realizada para posterior cultivo celular, como descrito a seguir. 


\subsubsection{Cultura de células mesenquimais da medula óssea de ratas}

A cultura de células tronco mesenquimais obtidas da medula óssea dos fêmures das ratas foi realizada como descrito por Maniatopoulos et al. (1988). Os fêmures removidos foram transportados até o laboratório em meio de transporte $\alpha$ MEM (Alpha minimum essential medium eagle) (Gibco, Carlsbad, CA, EUA) suplementado com $3 \mu \mathrm{g} / \mathrm{mL}$ de fungizona (Gibco) e $500 \mu \mathrm{g} / \mathrm{mL}$ de gentamicina (Gibco). No fluxo laminar, os fêmures foram submetidos à antissepsia (clorexidina a 2,5\% e álcool $70^{\circ}$ por 1 minuto cada). Posteriormente, foi realizada a remoção de tecidos moles restantes nos fêmures com uma lâmina de bisturi intercalada com a permanência dos mesmos em meio de transporte por 15 minutos (três vezes). As epífises foram removidas e a medula óssea extraída do fêmur por meio de irrigação da diáfise utilizando meio de cultura.

As células foram mantidas em frascos de $75 \mathrm{~cm}^{2}$ (Corning, Corning, NY, EUA) com MTS (meio total suplementado), contendo a-MEM (Gibco), 10\% de soro fetal bovino (Gibco), dexametasona $10^{-7} \mathrm{M}$ (Sigma, St. Louis, MO, EUA), $5 \mu \mathrm{g} / \mathrm{mL}$ de ácido ascórbico (Gibco), $7 \mathrm{mM}$ de $\beta$-glicerofosfato (Sigma), 0,3 $\mu \mathrm{g} / \mathrm{mL}$ de fungizona (Gibco) e $50 \mu \mathrm{g} / \mathrm{mL}$ de gentamicina (Gibco).

Após atingirem subconfluência, as células foram liberadas enzimaticamente dos frascos de cultura pela adição de solução de ácido etilenodiamino tetra-acético (EDTA) $1 \mathrm{mM}$ (Gibco), 1,3 mg/mL de colagenase tipo II (Gibco) e tripsina a 0,25\% (Gibco) e colocadas em presença de quantidade suficiente de meio de cultura para interromper a ação enzimática. Posterior à centrifugação a 2000 rpm por 5 minutos para obtenção do precipitado celular, as células foram homogeneizadas em MTS e uma alíquota de $100 \mu \mathrm{L}$ desta solução, adicionada ao mesmo volume de corante azul de tripan $0,1 \%$ (Sigma), foi utilizada para contagem celular por meio de um 
contador de células automático (Countess automated cell counter ${ }^{\mathrm{tm}}$, Invitrogen, Carlsbad, CA, EUA). A primeira passagem celular foi utilizada para realização dos experimentos. As culturas celulares foram divididas em dois grupos experimentais: controle (células de ratas sem a indução da osteoporose) e ovariectomizado (células de ratas induzidas à osteoporose).

As células foram cultivadas em MTS, na densidade de $2 \times 10^{4}$ células por poço, em placas de cultura celular de 24 poços $(n=5)$. As culturas foram incubadas a $37 \stackrel{\circ}{\circ}$, em atmosfera umidificada contendo $5 \%$ de dióxido de carbono $\left(\mathrm{CO}_{2}\right)$ e $95 \%$ de ar atmosférico. Durante o tempo de cultivo, as células foram acompanhadas por meio de observação em microscópio de luz invertido (Axiovert 25, Zeiss, Alemanha) sendo os meios de cultura trocados a cada 3 ou 4 dias.

\subsubsection{Cultura de células da calvária de ratas}

Fragmentos de calvária foram obtidos dos mesmos animais. As células foram isoladas e cultivadas de acordo com métodos descritos por Mailhot e Borke (1998) e Maniatopoulos et al. (1988), com protocolo já estabelecido no laboratório de cultura de células da Faculdade de Odontologia de Ribeirão Preto.

Os fragmentos foram triturados, transferidos para um tubo de centrífuga estéril para digestão através da adição de colagenase tipo II (Gibco) na concentração de $1 \mathrm{mg} / \mathrm{mL}$ e colocados em banho-maria a $37{ }^{\circ} \mathrm{C}$ sob agitação constante. Após 15 minutos de digestão, o sobrenadante foi removido e transferido para outro tubo de centrífuga contendo metade do volume de meio de cultura para inativação da colagenase. Este procedimento foi realizado três vezes. O sobrenadante da primeira digestão foi descartado e o das duas últimas foram centrifugados a $2000 \mathrm{rpm}$ por 5 minutos. Os sobrenadantes, resultantes da 
centrifugação, foram removidos e as células e fragmentos, ressuspensos em MTS e colocados em garrafas de cultura de $75 \mathrm{~cm}^{2}$.

Ao atingirem subconfluência, as células foram removidas dos frascos de cultura por meio de EDTA $1 \mathrm{mM}$ (Gibco), tripsina 0,25\% (Gibco) e 1,3 mg/mL de colagenase tipo II (Gibco), contadas utilizando o contador automático (Invitrogen) e a primeira passagem foi utilizada para cultivo em placas de 24 poços a uma densidade celular de $2 \times 10^{4}$ células por poço $(n=5)$. Durante todo o período de cultura as células foram mantidas em ambiente úmido com $5 \%$ de $\mathrm{CO}_{2}$ e $95 \%$ de ar atmosférico, e o meio de cultura trocado a cada 3 ou 4 dias. Assim como na cultura de células mesenquimais, as células osteoblásticas foram divididas em dois grupos experimentais: controle e ovariectomizado.

\subsection{Ensaios bioquímicos}

\subsubsection{Proliferação celular}

Ao final de 3, 7 e 10 dias, as células dos grupos experimentais foram lavadas três vezes com solução de PBS (Phosphate-buffered saline) (Gibco) aquecida a 37 ${ }^{\circ} \mathrm{C}$ e depois adicionado $1 \mathrm{~mL}$ por poço da solução de tripsina e EDTA, levadas para a incubadora por 5 minutos para posterior transferência para tubos eppendorf de 2 $\mathrm{mL}$. A esta solução foi adicionado $500 \mu \mathrm{L}$ de meio suplementado para inativação da tripsina. Em seguida, $100 \mu \mathrm{L}$ da suspensão de células e $100 \mu \mathrm{L}$ de azul de tripan foram homogeneizados, dos quais $10 \mu \mathrm{L}$ foram inseridos em slides para contador de células automático (Invitrogen). A proliferação celular foi expressa em número de células $\times 10^{4}$ por poço. 


\subsubsection{Viabilidade celular}

Aos 3, 7 e 10 dias de cultura, a viabilidade celular foi avaliada pelo ensaio colorimétrico MTT \{brometo de [3-(4,5-dimetiltiazol-2-il)-2,5-difeniltetrazolio]\} (Sigma).

Após remoção do meio de cultura, as células foram incubadas com solução de MTT + MTS por 4 horas a $37^{\circ} \mathrm{C}$, em atmosfera umidificada contendo $5 \%$ de $\mathrm{CO}_{2}$ e $95 \%$ de ar atmosférico. Passado esse período, o meio de cultura foi retirado dos poços e, em seguida, adicionado $1 \mathrm{~mL}$ de solução de isopropanol ácido (Merck, Darmstadt, Alemanha) em cada poço sob agitação por 5 minutos, para a solubilização completa do precipitado formado. Alíquotas de $150 \mu \mathrm{L}$ foram retiradas dos poços e transferidas para uma placa de 96 poços para leitura em espectrofotômetro ( $\mu$ Quant, Bio-tek Instruments Inc., Winooski, VT, EUA) em comprimento de onda de $570 \mathrm{~nm}$.

\subsubsection{Conteúdo de proteína total e atividade de fosfatase alcalina (ALP)}

Após 7, 10 e 14 dias de cultura celular, removeu-se o meio de cultura e os poços foram lavados três vezes com PBS (Gibco) aquecido a $37^{\circ} \mathrm{C}$ para remoção das células não aderidas e do meio de cultura sobressalente. Em seguida, os poços foram preenchidos com $1 \mathrm{~mL}$ de solução de lauril sulfato de sódio $0,1 \%$ (Sigma) e deixados à temperatura ambiente (TA) por 30 minutos. Ao final deste tempo, deu-se início aos ensaios:

a) Proteína total: a dosagem de proteína foi realizada seguindo o método de Lowry (Lowry et al., 1951). Para isso, $500 \mu \mathrm{L}$ da amostra contida em cada poço da placa de cultura foram transferidos ao respectivo tubo de ensaio, ao qual foi adicionado $500 \mu \mathrm{L}$ do reagente de Lowry (Sigma). Os tubos foram agitados 
vigorosamente e deixados em TA por 20 minutos. Após este período, $250 \mu \mathrm{L}$ da solução de Folin \& Ciocaulteau's phenol reagent (Sigma) foram adicionados aos tubos, que após agitação, ficaram em TA por 30 minutos para desenvolvimento da coloração azul. Passado o tempo, a absorbância de cada tubo foi determinada em um espectrofotômetro (Bio-Tek), em comprimento de onda de 680 nm. O conteúdo de proteína total de cada poço foi calculado com base na construção de uma curva padrão a partir de albumina bovina (Sigma). Os resultados foram utilizados para normalização da atividade de fosfatase alcalina.

b) Atividade de $A L P$ : foi determinada através da liberação de timolftaleína pela hidrólise do substrato timolftaleína monofosfato, utilizando o kit comercial (Labtest Diagnostica SA, Lagoa Santa, MG, Brasil) e seguindo as instruções do fabricante. Foram utilizados tubos de ensaio para os grupos testes, padrão e branco. Em todos os tubos foram adicionados $50 \mu \mathrm{L}$ de substrato e $500 \mu \mathrm{L}$ de solução tampão; somente no tubo padrão foram acrescentados $50 \mu \mathrm{L}$ da solução padrão. Posteriormente, todos os tubos foram colocados em banho-maria a $37^{\circ} \mathrm{C}$, para a realização do experimento. Acrescentou-se $50 \mu \mathrm{L}$ das amostras aos respectivos tubos testes em uma etapa realizada em intervalo máximo de 10 minutos. Decorrido o tempo, $2 \mathrm{~mL}$ do reagente de cor foram adicionados a todos os tubos de ensaio e, em seguida, determinou-se a absorbância em espectrofotômetro (Bio-Tek), no comprimento de onda de $590 \mathrm{~nm}$. Os dados da atividade de ALP foram normalizados pelo conteúdo de proteína total. 


\subsubsection{Formação e quantificação de matriz mineralizada}

A formação de matriz mineralizada foi avaliada ao final de 14 e 21 dias de experimento. Após remoção do meio de cultura, os poços foram lavados três vezes com PBS (Gibco) aquecido a $37^{\circ} \mathrm{C}$, preenchidos com formalina $10 \%$ e mantidos a $4^{\circ} \mathrm{C}$. Decorridas 24 horas, após remoção da formalina, os poços foram desidratados à TA em séries crescentes de álcoois $\left(30^{\circ}, 50^{\circ}, 70^{\circ}\right.$ e $\left.100^{\circ}\right)$ e a duração da desidratação para cada graduação alcoólica foi de 1 hora. Após secagem, os poços foram corados com vermelho de alizarina a $2 \% \mathrm{pH} \mathrm{4,2} \mathrm{(Sigma)} \mathrm{por} 10$ minutos e as áreas de mineralização ricas em cálcio evidenciadas pela coloração vermelha.

Para quantificação da coloração segundo método de Gregory et al. (2004), $280 \mu \mathrm{L}$ de ácido acético a 10\% (Labsynth, Lab Ltda, Diadema, SP, Brasil) foram acrescentados a cada poço e as placas deixadas sob agitação suave por 30 minutos. A camada de células foi raspada com a ponteira e a solução transferida para tubos eppendorf de $1,5 \mathrm{~mL}$, aquecida a $85^{\circ} \mathrm{C}$ por 10 minutos e transferida para o gelo por 5 minutos. Os tubos foram centrifugados a 13.000 rpm durante 20 minutos. Um volume de $150 \mu \mathrm{L}$ do sobrenadante foi transferido para uma placa de 96 poços (Corning) e $40 \mu \mathrm{L}$ de hidróxido de amônia a 10\% (Quimibras, Rio de Janeiro, RJ, Brasil) foram adicionados. A leitura foi realizada em espectrofotômetro (Bio-Tek) em um comprimento de onda de $405 \mathrm{~nm}$.

\subsection{Análise da expressão gênica por reação em cadeia de polimerase em tempo real (Real-time PCR)}

Após 3, 7 e 10 dias de experimento o meio de cultura foi removido dos poços e adicionado o reagente Trizol LS (Invitrogen) à TA, por 5 minutos, sob agitação por pipetagem. As amostras foram transferidas para tubos eppendorf e armazenadas em 
freezer a $-20^{\circ} \mathrm{C}$ por 48 horas. Passado esse período, realizou-se a extração do RNA total utilizando o kit SV Total RNA Isolation System (Promega, Madison, WI, EUA), de acordo com as especificações do fabricante. Em seguida, o RNA total foi quantificado em diferentes comprimentos de onda (260, 280, 230 e $320 \mathrm{~nm})$ em espectrofotômetro (GE Healthcare, Milwaukee, WI, EUA) e sua integridade avaliada por meio de eletroforese em gel de agarose desnaturante 1,5\% (m/v).

Os tampões para a realização da eletroforese foram preparados com água previamente tratada com dietilpirocarbonato (DEPC, Sigma). Para o preparo da água adicionou-se $1 \mathrm{~mL}$ de DEPC em $999 \mathrm{~mL}$ de água deionizada, sendo esta mistura incubada em TA por 24 horas e autoclavada por 30 minutos. O gel foi preparado dissolvendo-se $3 \mathrm{~g}$ de agarose (Gibco) em $144 \mathrm{~mL}$ de água previamente tratada com DEPC. Em seguida, a mistura foi aquecida, em banho-maria, a $65^{\circ} \mathrm{C}$ e, então, adicionados $36 \mathrm{~mL}$ de formaldeído a 12,3 M (Merck, HE, Alemanha), 7 LL de GelRed (Biotium, Inc, Hayward, CA, EUA) e $20 \mathrm{~mL}$ de tampão de corrida, constituído de 50 mM acetato de sódio (Merck), 5 mM EDTA (Merck) e 100 mM de ácido 3-[Nmorfolino]propanosulfônico (MOPS, Sigma). A mistura foi despejada em formas adequadas para a moldagem do gel.

Para o preparo das amostras, foram adicionados $2 \mu \mathrm{g}$ de RNA total, $2 \mu \mathrm{L}$ de tampão de corrida, $4 \mu \mathrm{L}$ de formaldeído a 12,3 M e $10 \mu \mathrm{L}$ de formamida (Merck). Essa mistura foi aquecida a $85^{\circ} \mathrm{C}$ por dez minutos e, posteriormente, submetida ao resfriamento a $4^{\circ} \mathrm{C}$ por 5 minutos. Em seguida, adicionou-se o tampão de amostra, composto por $50 \%$ de glicerol $(\mathrm{v} / \mathrm{v}), 0,25 \%$ de azul de bromofenol $(\mathrm{m} / \mathrm{v}), 0,25 \%$ de xileno cianol (m/v) e $10 \mathrm{nM}$ de EDTA em água DEPC. A eletroforese foi conduzida a $60 \mathrm{~V}$ durante 1 a 3 horas, utilizando-se tampão de corrida. Após esse período o gel foi visualizado por meio de iluminação com luz ultravioleta (UV) a $300 \mathrm{~nm}$. A 
integridade do RNA foi verificada pela visualização de duas subunidades (18S e 28S) do RNA ribossômico presentes em organismos eucariotos.

O passo seguinte foi a confecção da fita de cDNA a partir de $1 \mu \mathrm{g}$ de RNA total. Este procedimento foi realizado no termociclador Mastercycle Gradient (Eppendorf, Hamburg, Alemanha) por meio de reação com a enzima transcriptase reversa, utilizando o kit High-capacity cDNA Reverse Transcription (Applied Biosystems, Fort City, CA, EUA), de acordo com as instruções do fabricante.

Para as reações de Real-time PCR, foram utilizadas sondas TaqMan (Applied Biosystems) para genes-alvo, sendo feitas em equipamento CFX96 (BioRad, Hercules, CA, EUA). As reações foram realizadas em quadruplicata, utilizando: $5 \mu \mathrm{L}$ de $\operatorname{TaqMan}^{\circledR}$ Gene Expression Master Mix, 0,5 $\mu \mathrm{L}$ de sonda TaqMan para os genes de interesse (Tabela 1) e 4,5 $\mu \mathrm{L}$ de cDNA $(11,25 \mathrm{ng}$ ), para um volume final de 10 $\mu \mathrm{L} /$ reação.

As reações de amplificação consistem em 2 minutos a $50 \stackrel{\circ}{ } \mathrm{C}, 10$ minutos a 95 ${ }^{\circ} \mathrm{C}$, e quarenta ciclos de 15 segundos a $95^{\circ} \mathrm{C}$ e 1 minuto a $60{ }^{\circ} \mathrm{C}$ (desnaturação e extensão). Os resultados foram analisados com base no valor de Ct (cicle threshold, ou ciclo limiar), sendo este o ponto correspondente ao número de ciclos em que a amplificação das amostras atinge um limiar (determinado entre o nível de fluorescência dos controles negativos e a fase de amplificação exponencial das amostras). Como controle endógeno, avaliou-se a expressão do gene para a enzima Hprt1 (hypoxanthine guanine phosphoribosyl transferase 1). Os níveis de expressão do controle endógeno foram utilizados para a normalização dos níveis de expressão do gene alvo e uma amostra negativa (água) foi submetida à reação com cada sonda TaqMan utilizada. A normalização e quantificação relativa da expressão gênica foram realizadas pelo método de $2^{-\Delta \Delta C T}$ (Livak e Schmittgen, 2001). Usando o 
método de $2^{-\Delta \Delta C T}$, os dados foram representados como diferença (em vezes) na expressão gênica normalizada pelo Hprt1.

Tabela 1: Genes avaliados.

\begin{tabular}{|c|c|c|c|c|}
\hline Gene alvo & Nome do Gene & $\begin{array}{l}\text { Identificação do } \\
\text { Ensaio }\end{array}$ & Número Acesso & $\begin{array}{c}\text { Amplicon } \\
\left(\mathrm{pb}^{*}\right)\end{array}$ \\
\hline Alpl & $\begin{array}{l}\text { alkaline phosphatase, } \\
\text { liver/bone/kidney }\end{array}$ & Rn01516028_m1 & NM_013059.1 & 68 \\
\hline Runx2 & $\begin{array}{l}\text { runt-related transcription } \\
\text { factor } 2\end{array}$ & Rn01512298_m1 & NM_053470.2 & 86 \\
\hline Rank-I & $\begin{array}{l}\text { tumor necrosis factor (ligand) } \\
\text { superfamily, member } 11\end{array}$ & Rn00589289_m1 & NM_057149.1 & 69 \\
\hline Opg & $\begin{array}{l}\text { tumor necrosis factor } \\
\text { receptor superfamily, } \\
\text { member } 11 \mathrm{~b}\end{array}$ & Rn00563499_m1 & NM_012870.2 & 75 \\
\hline Oc & $\begin{array}{l}\text { bone gamma- } \\
\text { carboxyglutamate (gla) } \\
\text { protein }\end{array}$ & Rn00566386_g1 & NM_013414.1 & 104 \\
\hline Esr1 & estrogen receptor 1 & Rn01640372_m1 & NM_012689.1 & 67 \\
\hline Esr2 & estrogen receptor 2 & Rn00562610_m1 & NM_012754.1 & 89 \\
\hline Hprt1 & $\begin{array}{c}\text { hypoxanthine } \\
\text { phosphoribosyltransferase } 1\end{array}$ & Rn01527840_m1 & NM_012583.2 & 64 \\
\hline
\end{tabular}

\subsection{Análise estatística}

Os dados quantitativos obtidos foram submetidos aos testes de aderência à curva normal e homogeneidade de variâncias. Constatada a normalidade da distribuição amostral, foi aplicada a análise de variância (ANOVA), seguida de pós- 
teste, quando apropriado. Caso contrário, foi aplicado o teste não-paramétrico de Kruskal-Wallis, seguido de pós-teste de Mann-Whitney quando necessário. O nível de significância foi estabelecido em $5 \%$. Toda a análise estatística foi realizada por meio do software SPSS 20.0. Os resultados apresentados foram provenientes de ensaios realizados em triplicata. 
Qesultados 


\section{RESULTADOS}

\subsection{Proliferação celular}

Ao final de 3 dias, a proliferação celular foi similar nos grupos de células provenientes da calvária de ratas controle (CC) e com osteoporose (CO), não havendo diferença significante entre elas, enquanto que as células originárias da medula de ratas com osteoporose (MO) apresentaram uma menor proliferação quando comparado ao seu grupo controle (MC), com $p<0,01$. Nos períodos experimentais de 7 e 10 dias, observou-se que o grupo CO apresentou menor proliferação celular quando comparado ao grupo CC $(p<0,01)$, o que não ocorreu na medula óssea, onde o grupo $\mathrm{MO}$ mostrou um aumento na proliferação quando comparado ao grupo $\mathrm{MC}(p<0,01)$.

Ao comparar os grupos controles (CCxMC), notou-se maior proliferação nas células da calvária ao longo dos períodos experimentais $(p<0,05)$. Tal padrão não foi observado nas células da medula, que demonstraram uma queda na proliferação ao atingir o $10^{\circ}$ dia de cultura. Ainda pode ser observado que nos grupos de células originárias da medula óssea, MO mostrou maior proliferação que o grupo $\mathrm{CO}$ aos 7 e 10 dias $(p<0,05)$. 


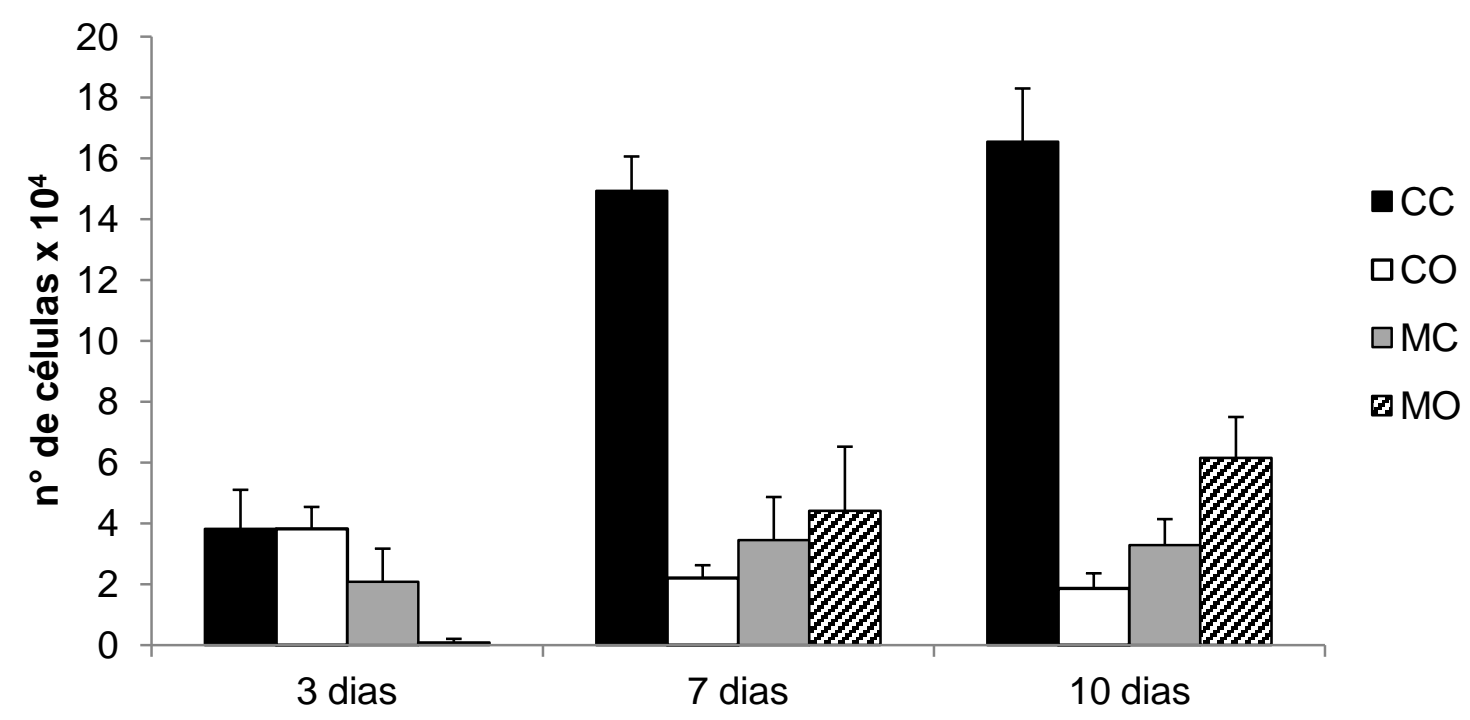

Figura 7 - Avaliação da proliferação de células osteoblásticas da calvária e medula óssea de ratas controle e com osteoporose aos 3, 7 e 10 dias de cultura celular.

\subsection{Viabilidade celular}

No ensaio colorimétrico (MTT), o comportamento foi diferente entre as células dos grupos CC e CO durante os períodos experimentais $(p<0,05)$. Enquanto $o$ grupo CC apresentou um pico aos 7 dias de cultura, o grupo CO demonstrou um aumento da viabilidade no decorrer dos períodos de cultura. Entre os grupos MC e MO, exceto aos 7 dias, a viabilidade celular foi maior no grupo com osteoporose que no grupo controle $(p<0,01)$.

Diferenças significantes foram notadas ao comparar os grupos controles (CCxMC) e com osteoporose (COxMO), onde as células provenientes da calvária apresentaram maior viabilidade que as células diferenciadas da medula óssea ( $p<$ $0,05)$ em todos os períodos de cultura. 


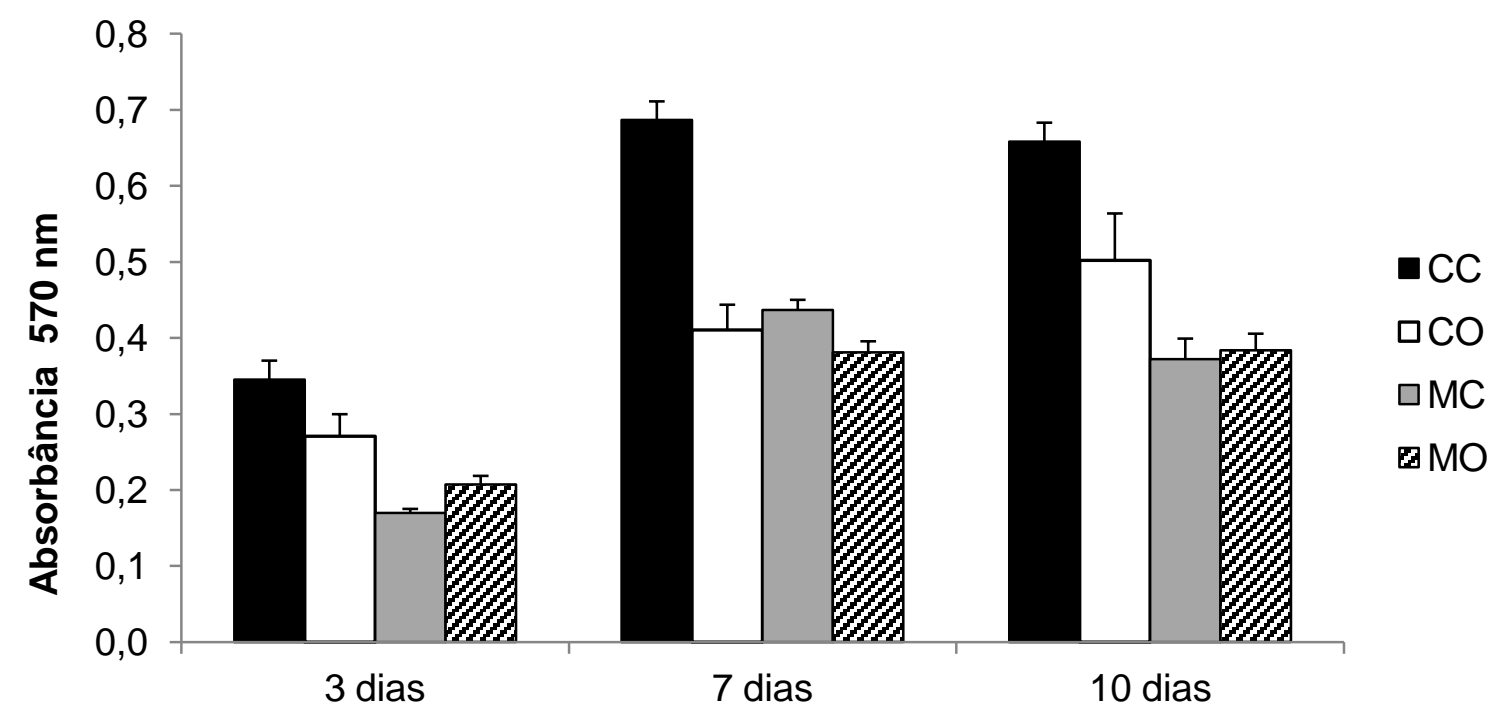

Figura 8 - Viabilidade celular de osteoblastos provenientes da calvária e medula óssea de ratas controle e com osteoporose aos 3, 7 e 10 dias de cultura celular, avaliada por meio de ensaio colorimétrico (MTT).

\subsection{Atividade de fosfatase alcalina (ALP)}

Aos 7 dias de cultura não houve diferença na atividade de ALP entre os grupos estudados. Aos 10 e 14 dias o grupo CC apresentou um aumento da atividade quando comparado ao grupo $\mathrm{CO}(p<0,01)$. Já nas células originárias da medula óssea o grupo MO apresentou uma maior ALP que seu respectivo grupo controle $(p<0,01)$ nestes mesmos períodos, mostrando um pico aos 14 dias de cultura. Em uma análise entre os grupos controles (CC x MC) e com osteoporose $(\mathrm{CO} \times \mathrm{MO})$ aos 10 e 14 dias, todos mostraram diferença significativa com $p<0,01$. 


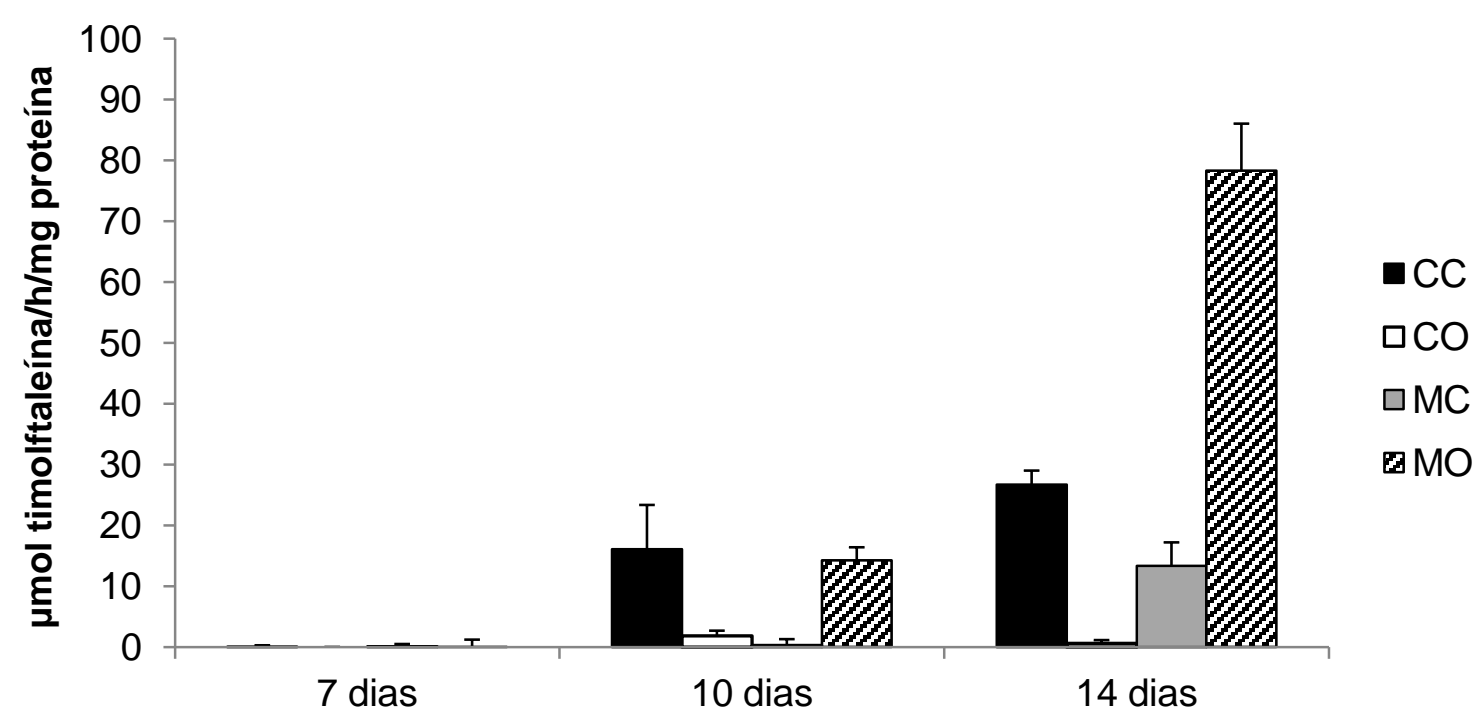

Figura 9 - Atividade de fosfatase alcalina de células osteoblásticas obtidas da calvária e medula óssea de ratas controle e com osteoporose aos 7, 10 e 14 dias de cultura celular, normalizada pelo conteúdo de proteína total.

\subsection{Quantificação de nódulos de mineralização}

Após a coloração com vermelho de alizarina, foi observado que a quantidade de nódulos mineralizados na base dos poços foi maior no grupo CC quando comparado ao grupo CO aos 14 e 21 dias. Já nos poços ocupados por células da medula óssea, foi observado, principalmente aos 21 dias, que a quantidade de nódulos presentes foi maior no grupo $\mathrm{MO}$ em relação ao grupo MC. Assim como na análise qualitativa, a avaliação quantitativa dos nódulos de mineralização mostrou um aumento no grupo das células obtidas da calvária nos dois períodos avaliados, onde o grupo CC apresentou maior mineralização que o grupo $C O(p<0,01)$. Esse comportamento não foi observado nos grupos de células da medula óssea, uma vez que o grupo MO obteve maior quantidade de nódulos mineralizados que o grupo MC, porém tal diferença não foi significante. Nos grupos de origem celular diferente foi observada significância estatística somente entre os grupos $\mathrm{CO}$ e $\mathrm{MO}(p<0,01)$. 

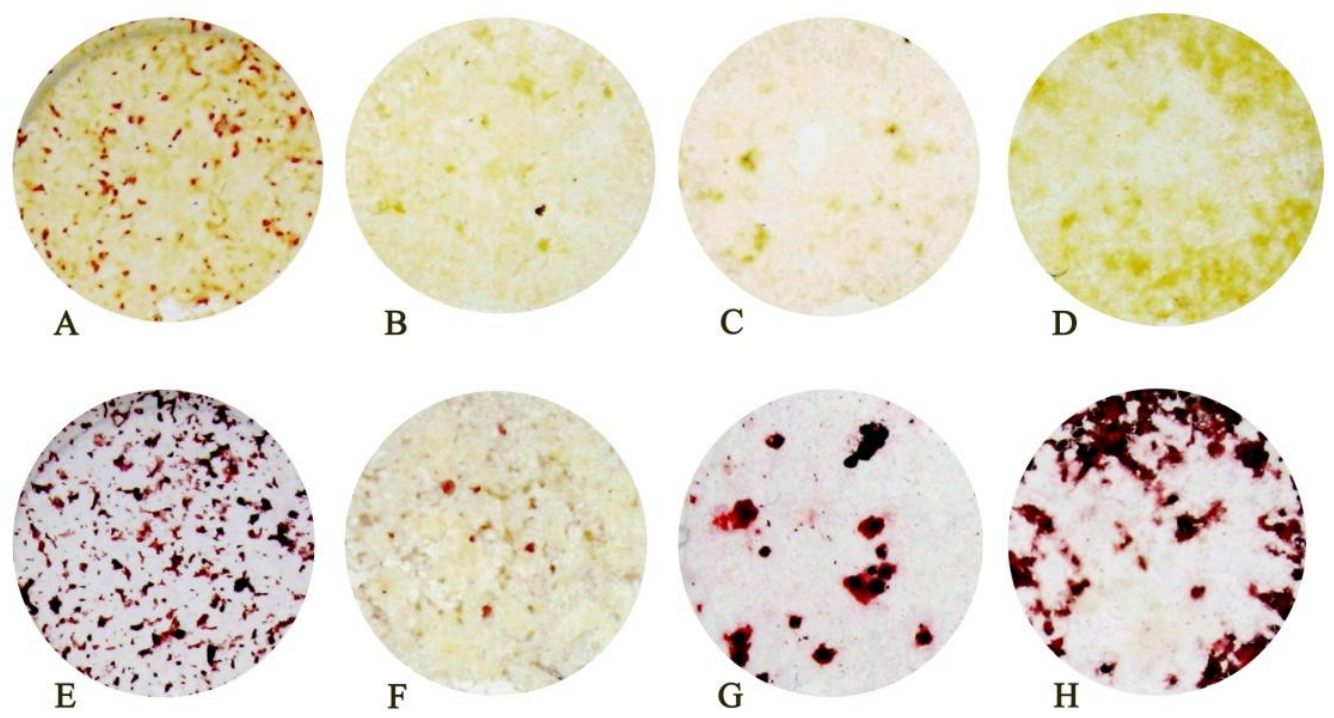

Figura 10 - Nódulos de mineralização de células osteoblásticas obtidas da calvária e medula óssea de ratas controle e com osteoporose nos períodos de 14 e 21 dias de cultura celular. A) Grupo CC 14 dias; B) Grupo CO 14 dias; C) Grupo MC 14 dias; D) Grupo MO 14 dias; E) Grupo CC 21 dias; F) Grupo CO 21 dias; G) Grupo MC 21 dias e H) MO 21 dias.

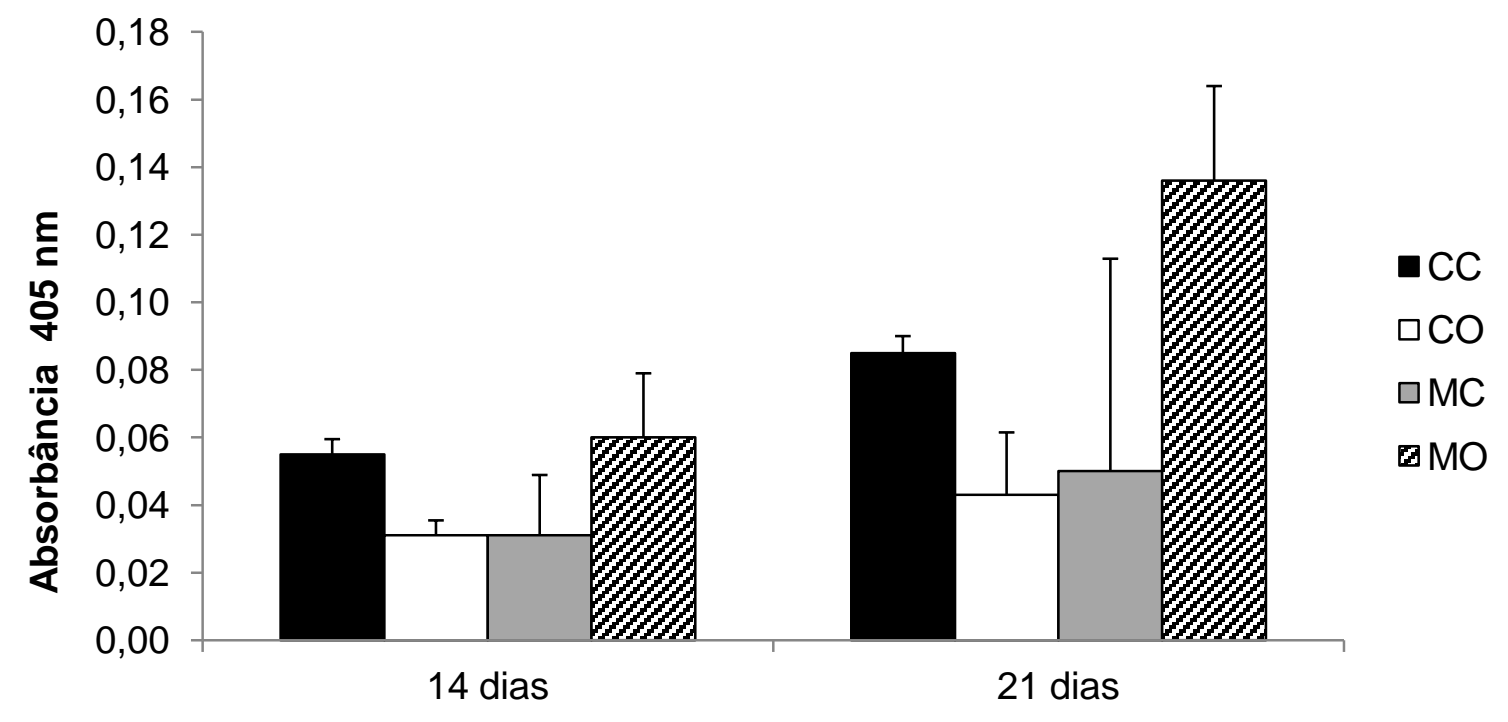

Figura 11 - Quantificação de nódulos de mineralização de células osteoblásticas da calvária e medula óssea de ratas controle e com osteoporose aos 14 e 21 dias, por meio da extração de vermelho de alizarina. 


\subsection{Análise da expressão gênica por reação em cadeia de polimerase em tempo real (Real-time PCR)}

Para a análise da expressão gênica por meio de PCR, foi analisada a integridade do RNA por meio de gel de agarose.

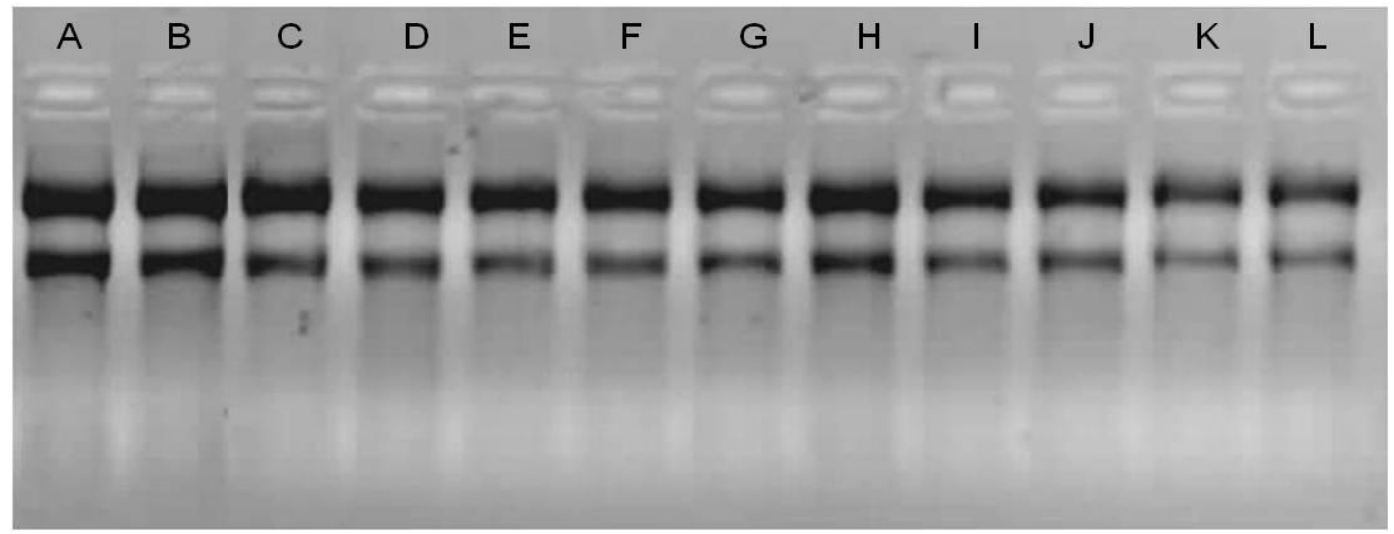

Figura 12 - Análise da integridade do RNA por meio de gel de agarose com brometo de etídio. A) CC 3 dias; B) CC 7 dias; C) CC 10 dias; D) MC 3 dias; E) MC 7 dias; F) MC 10 dias; G) MO 3 dias; H) MO 7 dias; I) MO 10 dias; J) CO 3 dias; K) CO 7 dias; L) CO 10 dias.

Após a realização do protocolo de PCR em tempo real, foi possível avaliar a expressão quantitativa dos genes propostos. Analisando a expressão de Runx2 (Runt-related transcription factor 2) (figura 13) observou-se que em todos os períodos experimentais o grupo controle da calvária apresentou maior expressão que o grupo $\mathrm{CO}(p<0,05)$. No entanto essa relação foi inversa para a medula óssea, onde o grupo MO mostrou uma expressão superior ao grupo controle (MC) ( $p$ $<0,05)$. Também foi possível notar que o grupo CO obteve menor expressão que o grupo MO $(p<0,05)$ em todos os tempos estudados. Comparando o grupo CC com MC observou-se um comportamento diferente ao longo dos períodos: aos 3 dias, a diferença entre eles não foi significante; aos 7, o grupo controle da calvária se 
sobressaiu em relação ao grupo MC $(p<0,05)$ e aos 10 dias, esse comportamento inverteu-se, com a expressão de Runx2 maior para o grupo MO $(p<0,05)$.

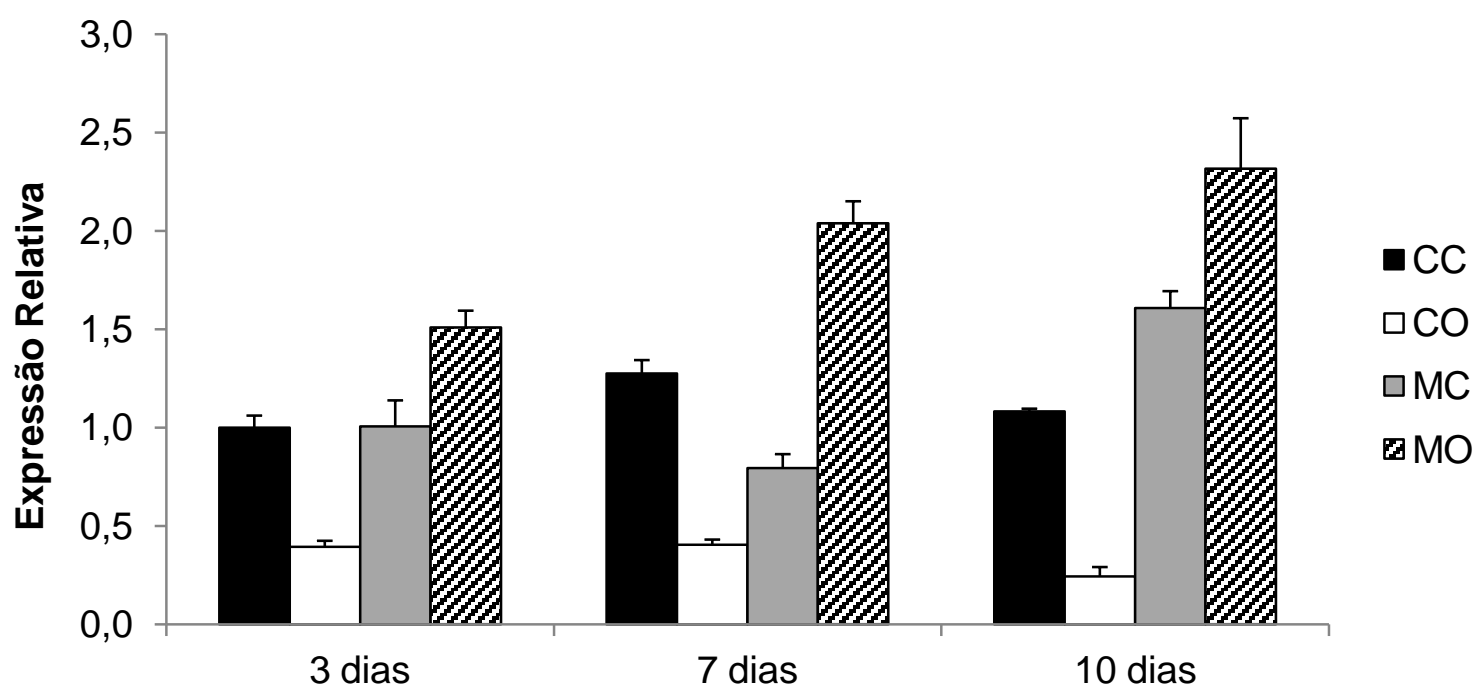

Figura 13 - Análise da expressão gênica de Runx2 em grupos de células obtidas da calvária e medula óssea de ratas controle (CC e $M C)$ e induzidas à osteoporose (CO e MO).

A expressão gênica de osteocalcina (Oc) (figura 14) mostrou que, ao longo dos períodos, o grupo CC teve maior expressão que o grupo $\mathrm{CO}(p<0,05)$, enquanto que $\mathrm{MC}$ apresentou valores menores que $\mathrm{MO}(p<0,05)$, exceto aos 3 dias, onde não houve diferença entre eles. Quando comparado o grupo CO com MO, nos três tempos avaliados, a expressão do primeiro foi menor que o segundo ( $p$ $<0,05)$, enquanto que ao analisar os grupos $\mathrm{CC}$ e $\mathrm{MC}$, a diferença foi significativa apenas aos 7 e 10 dias $(p<0,05)$. 


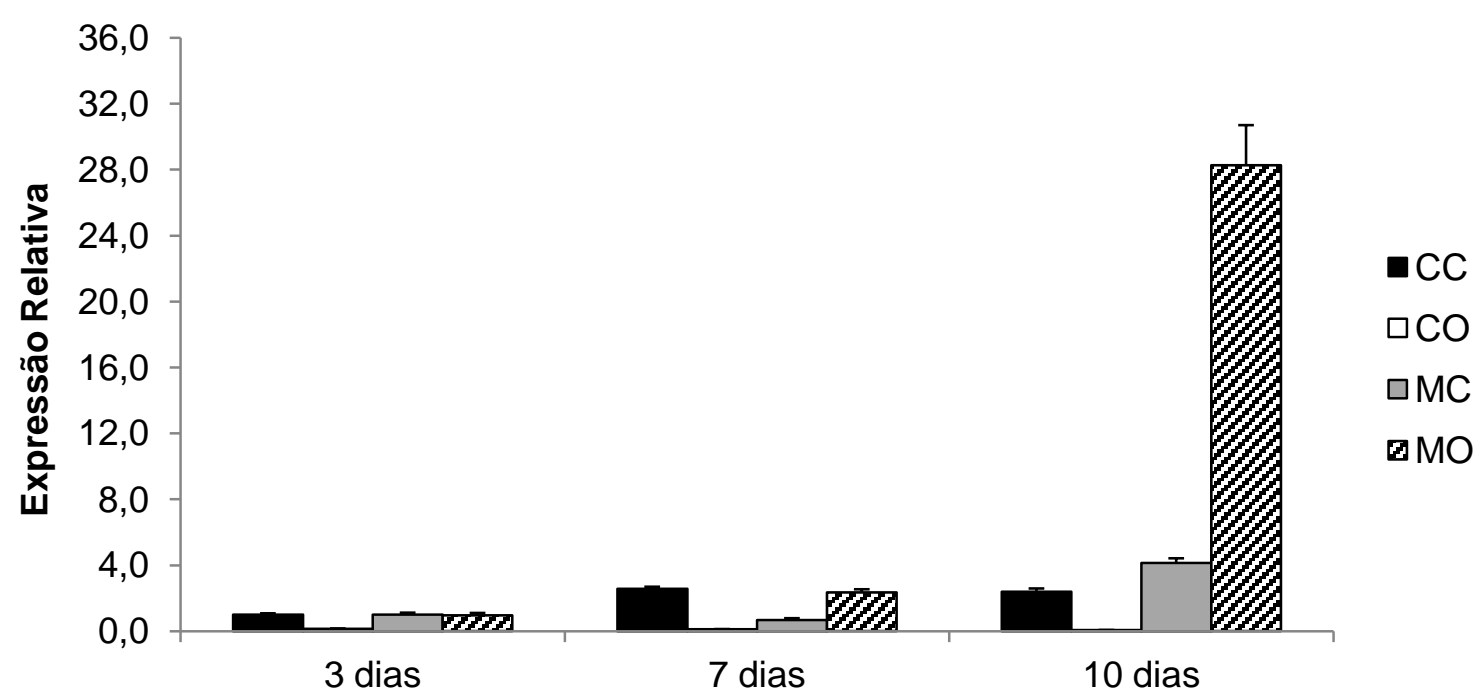

Figura 14 - Análise da expressão gênica de osteocalcina (Oc) em grupos de células obtidas da calvária e medula óssea de ratas controle (CC e $M C)$ e induzidas à osteoporose (CO e MO).

Ao analisar a expressão do gene fosfatase alcalina (Alpl) (figura 15) notou-se um padrão nos grupos estudados, onde o grupo CC apresentou valores maiores que $\mathrm{CO}(p<0,05)$ e, o grupo MC, valores menores que grupo $\mathrm{MO}(p<0,05)$ em todos os períodos. Quando houve a comparação entre calvária e medula óssea (CCxMC), observou-se um aumento significativo da expressão nas células da medula aos 10 dias $(p<0,05)$, assim como entre os grupos $\mathrm{CO}$ e $\mathrm{MO}$ aos $3,7, \mathrm{e} 10$ dias $(p<0,05)$. 


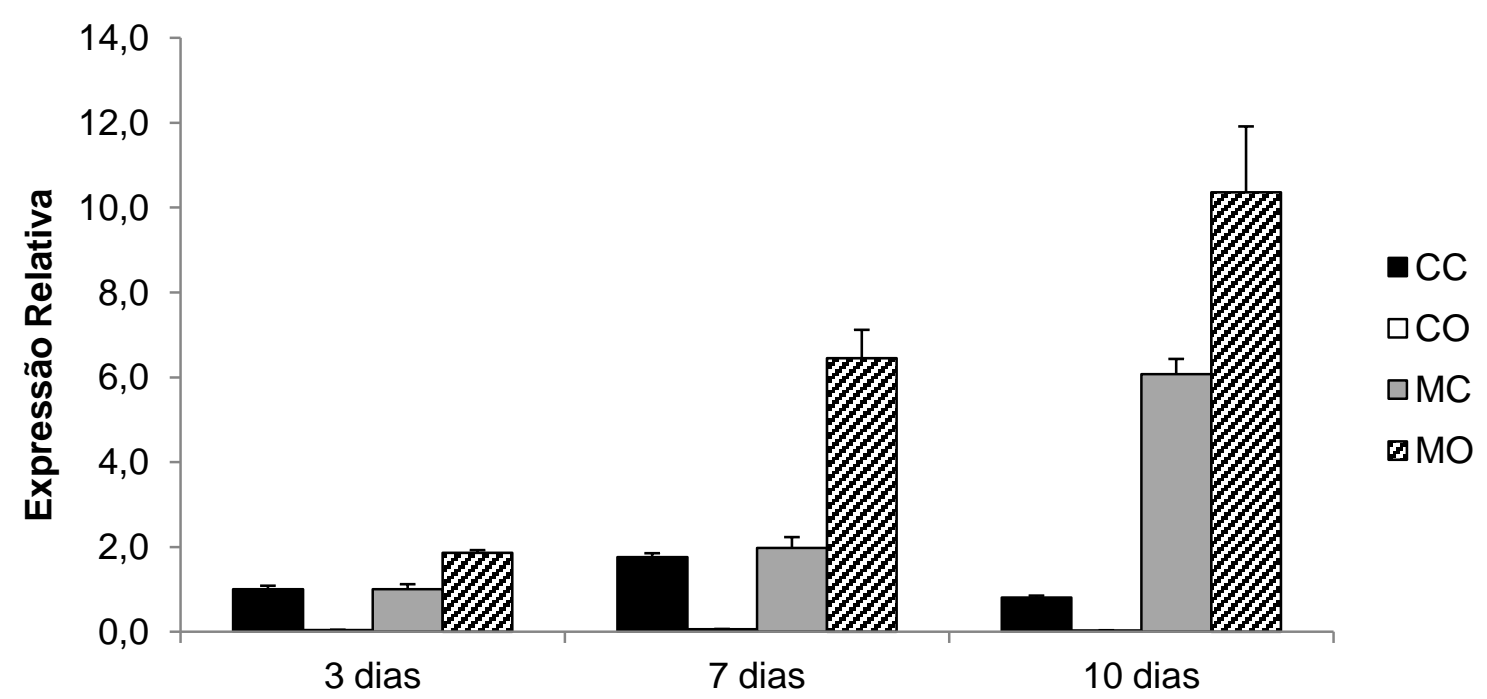

Figura 15 - Análise da expressão gênica de fosfatase alcalina (Alpl) em grupos de células da calvária e medula óssea de ratas controle (CC e MC) e induzidas à osteoporose (CO e MO).

Valores da expressão gênica de Rank-I (figura 16) se mantiveram maiores no grupo controle da calvária quando comparado ao grupo de células de ratas com osteoporose $(p<0,05)$. Já nas células da medula óssea, a expressão no grupo MO foi maior que no controle $(p<0,05)$, exceto aos 10 dias, onde a diferença entre eles não foi significativa. A comparação entre os grupos com origem celular diferente (MCxCC e MOxCO) também apresentou diferença estatística com $p<0,05$, com exceção aos 3 dias, quando o grupo CC foi similar ao grupo MC.

A expressão quantitativa de osteoprotegerina (Opg) (figura 17) foi maior no grupo CC quando comparado ao grupo $\mathrm{CO}(p<0,05)$ aos 7 e 10 dias, porém as células do grupo MC mostraram menor expressão deste gene que o grupo MO $(p<$ 0,05) em todos os tempos experimentais. O estudo entre os grupos da calvária e medula apresentaram diferença estatisticamente significativa nos três períodos avaliados, com exceção da comparação entre CC e MC aos 3 dias. Nos demais 
períodos, a expressão de CC foi maior que MC $(p<0,05)$ e MO maior que CO $(p<$ 0,05).

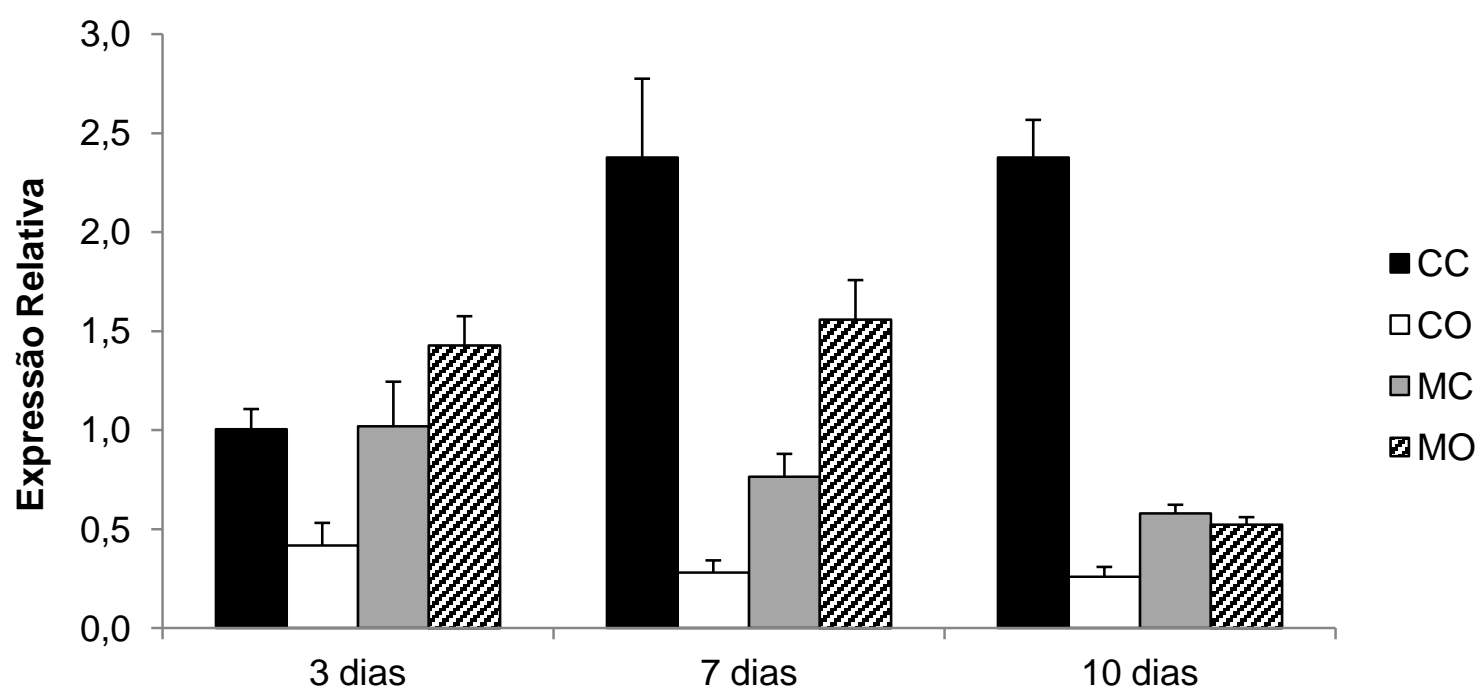

Figura 16 - Análise da expressão gênica de Rank-I em grupos de células obtidas da calvária e medula óssea de ratas controle (CC e $\mathrm{MC})$ e induzidas à osteoporose (CO e MO).

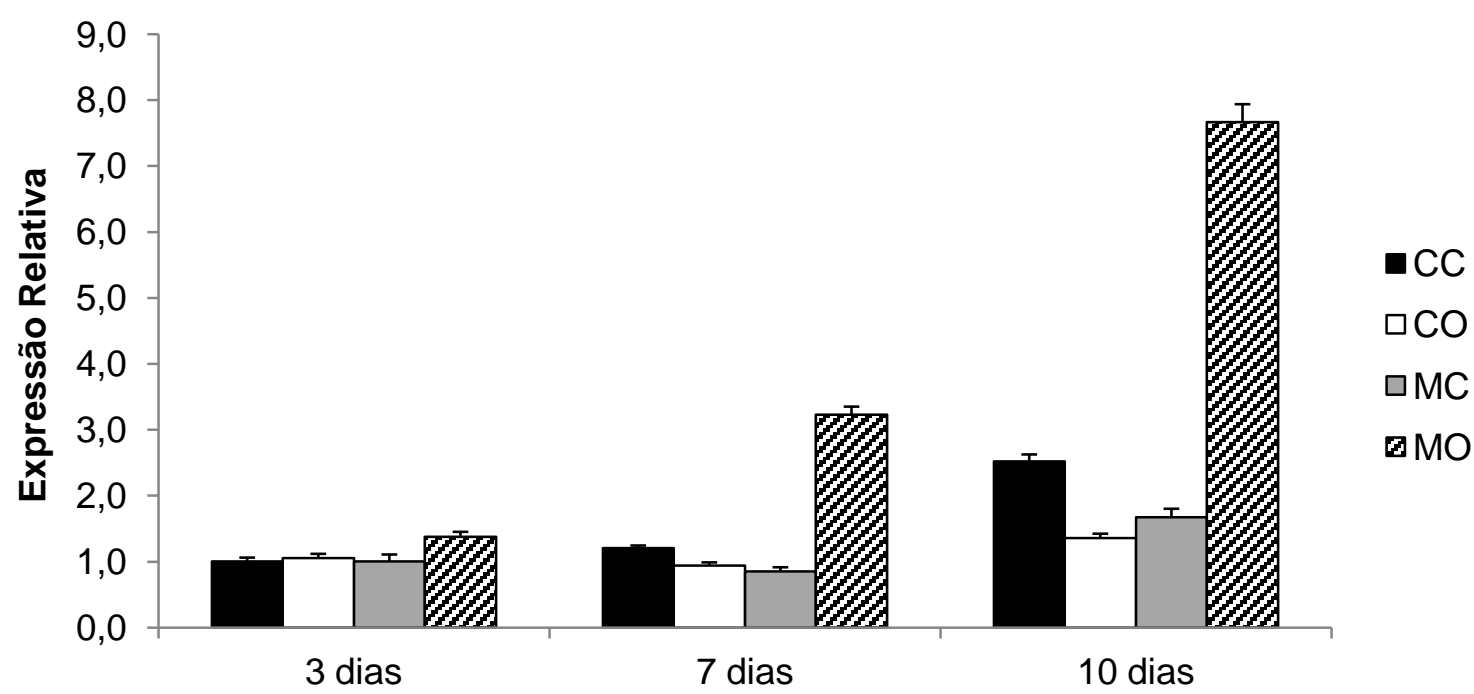

Figura 17 - Análise da expressão gênica de osteoprotegerina (Opg) em grupos de células da calvária e medula óssea de ratas controle (CC e $M C)$ e induzidas à osteoporose (CO e $\mathrm{MO})$. 
A razão Rank-I/Opg, obtida a partir da expressão desses genes, se manteve maior no grupo CC quando comparado ao grupo com osteoporose ao longo de todo o período avaliado $(p<0,05)$, com um pico aos 7 dias. O grupo controle das células originárias da medula óssea demonstrou valores mais altos que o grupo $\mathrm{MO}$ aos 7 e 10 dias $(p<0,05)$. Diferenças significativas $(p<0,05)$ foram encontradas na comparação dos grupos calvária e medula aos 7 e 10 dias, no entanto, aos 3 dias, essa diferença só pode ser observada entre os grupos $\mathrm{CO}$ e $\mathrm{MO}$.

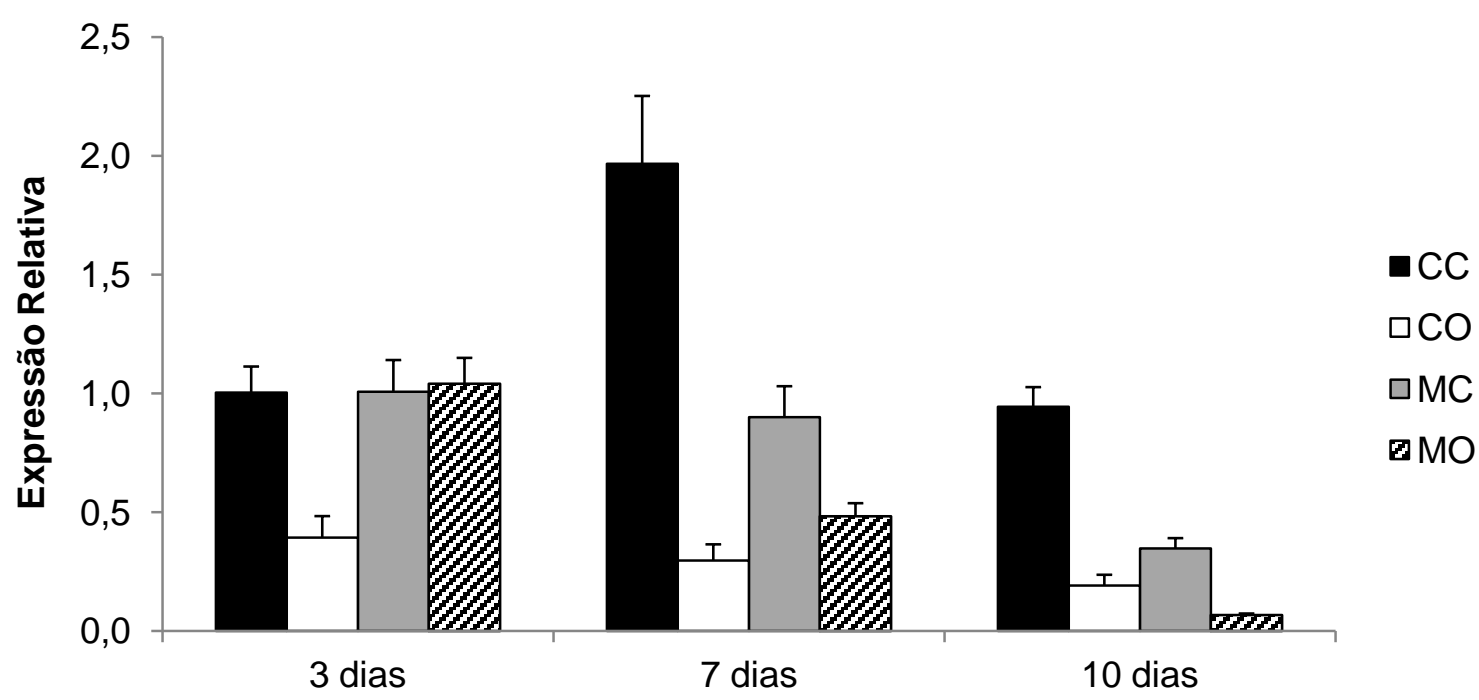

Figura 18 - Avaliação da razão Rank-l/Opg a partir de células da calvária e medula óssea de ratas controle (CC e MC) e osteoporóticas (CO e MO).

As células da medula óssea das ratas ovariectomizadas apresentaram maior expressão de receptor de estrógeno alfa (Era) que o seu grupo controle em todos os períodos analisados, sendo que aos 7 dias, houve a maior diferença entre eles $(p<$ 0,05); por outro lado, nas células provenientes da calvária, as células do grupo CC mantiveram a expressão desse receptor mais alta que no grupo osteoporótico $(p<$ 0,05 aos 7 dias de cultura). Ao comparar a calvária à medula, observou-se que no grupo $\mathrm{CO}$ a expressão de Era foi menor do que no grupo $\mathrm{MO}$, nos três períodos 
avaliados $(p<0,05)$; já a diferença entre CC e MC não foi significante em nenhum dos períodos.

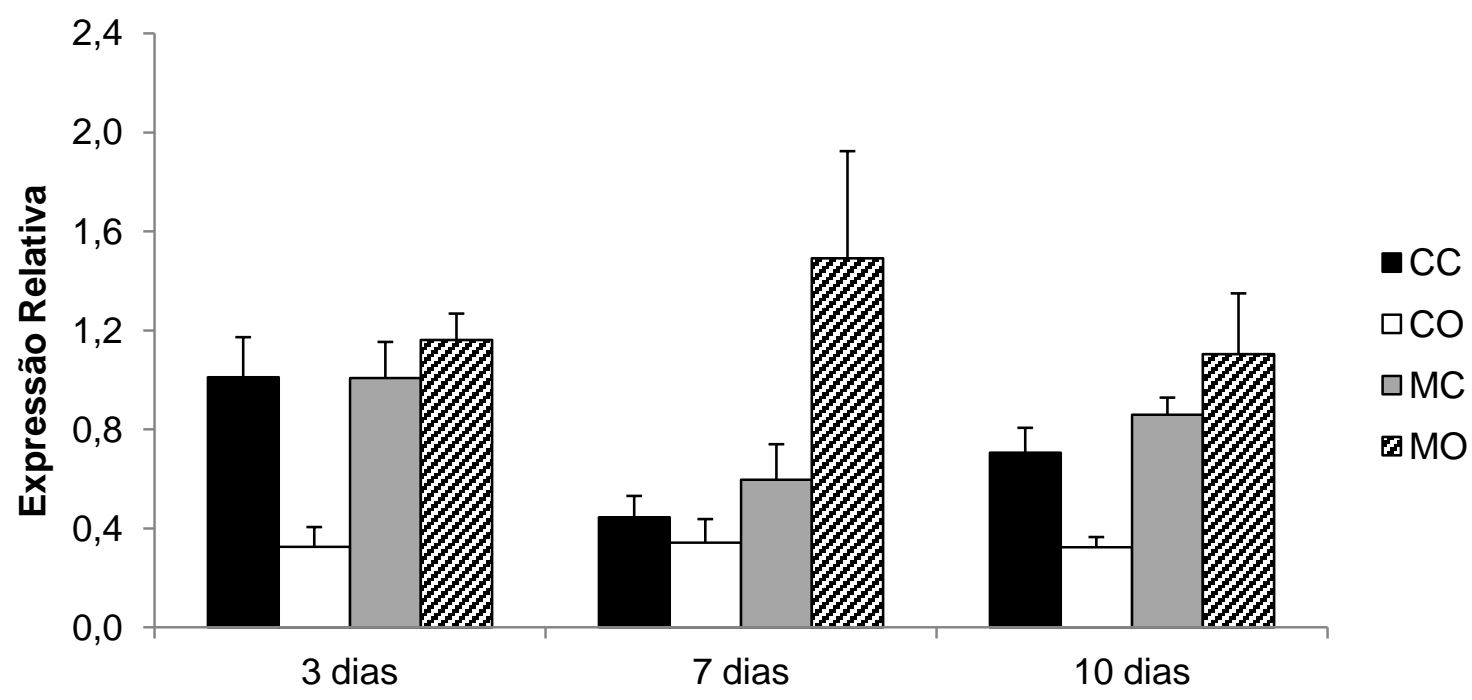

Figura 19 - Análise da expressão gênica de receptor de estrógeno alfa (Era) em grupos de células obtidas da calvária e medula óssea de ratas controle (CC e MC) e induzidas à osteoporose (CO e MO).

O receptor de estrógeno beta $(\operatorname{Er} \beta)$ foi o que apresentou maior variabilidade entre os grupos. Aos 3 e 7 dias, a expressão gênica do grupo CO foi maior que do grupo CC $(p<0,05)$; já aos 10 dias, o inverso foi observado $(p<0,05)$. Aos 3 e 10 dias, o grupo MC apresentou maior expressão que o grupo $\mathrm{MO}$, enquanto que aos 7 dias, o grupo MO teve uma expressão mais alta quando comparado ao grupo MC ( $p$ $<0,05)$. A comparação entre grupos de origem celular diferente também mostrou significância estatística. $\mathrm{O}$ grupo CC apresentou maior expressão que MC aos 7 e 10 dias $(p<0,05)$ enquanto que a expressão do $\operatorname{Er} \beta$ nas células obtidas da calvária de ratas ovariectomizadas foi maior em relação às células do grupo $\mathrm{MO}(p<0,05)$. 


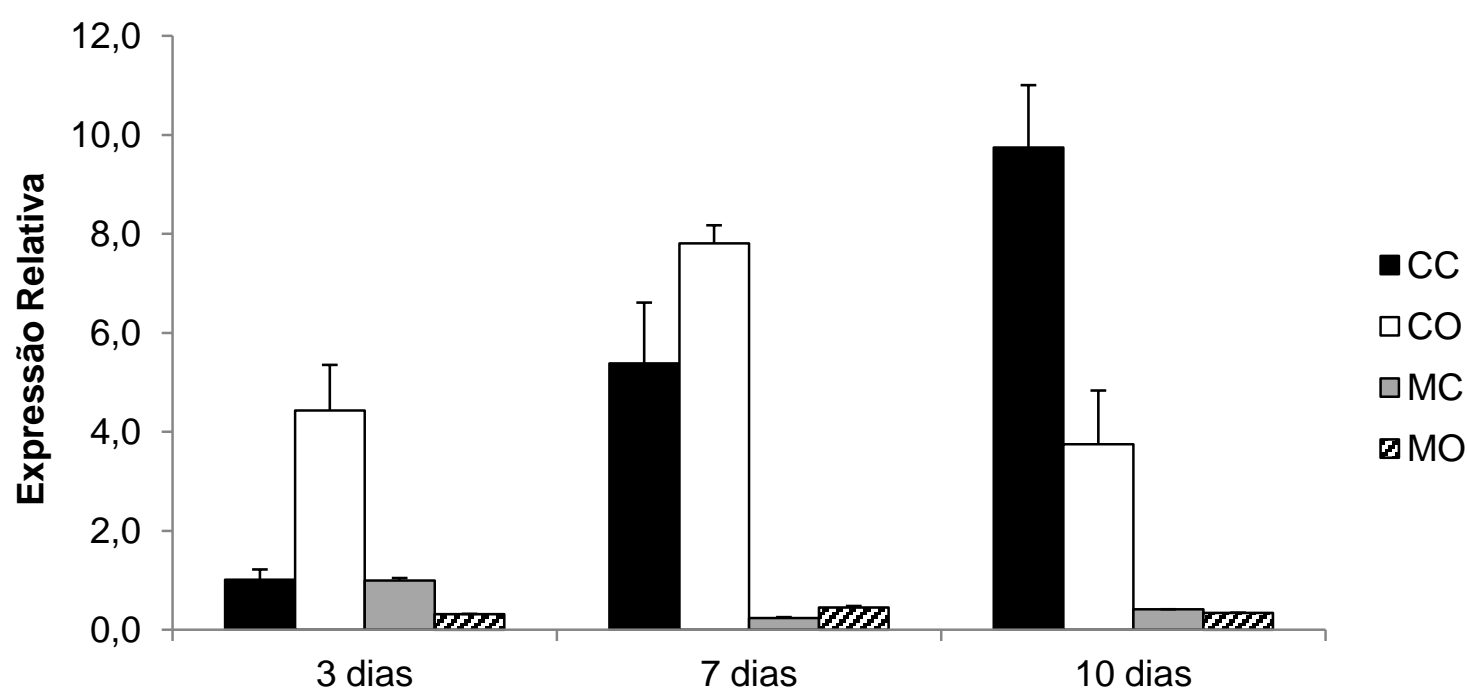

Figura 20 - Análise da expressão gênica de receptor de estrógeno beta $(\operatorname{Er} \beta)$ em grupos de células obtidas da calvária e medula óssea de ratas controle (CC e MC) e induzidas à osteoporose (CO e MO). 
(D)iscussĩu 


\section{DISCUSSÃO}

Considerada o segundo maior problema de saúde pública, de acordo com a Organização Mundial da Saúde (OMS), a osteoporose trata-se de uma doença assintomática e com alta prevalência entre os idosos, sendo as mulheres na pósmenopausa as mais atingidas. Devido à fragilidade óssea, o risco de fraturas aumenta nessa população, implicando em um problema clínico e social, uma vez que os portadores desta patologia comumente apresentam limitações para exercer suas atividades profissionais ou sociais, afetando, muitas vezes, a saúde emocional e impactando negativamente na qualidade de vida do paciente (Brandão et al., 2013; Dallanezi et al., 2011).

Frente a esses e outros problemas, constantes pesquisas estão sendo realizadas visando o entendimento desta patologia em nível celular, a fim de buscar novas drogas e terapias para a prevenção ou tratamento da osteoporose. Uma vez que a pesquisa com seres humanos ainda é de difícil acesso, as pesquisas com animais tornam-se frequentes.

O modelo ideal de animais de laboratório deve replicar uma condição humana com o máximo grau de fidelidade. Fatores de risco desta patologia como insuficiência de hormônios sexuais, terapia com drogas anti-inflamatórias e imunossupressoras, uso de álcool e tabaco e envelhecimento tem sido bem estabelecidos em animais (Turner et al., 2001).

Roedores e macacos são os principais animais utilizados para estabelecer um modelo de osteoporose (Duncan e Brown, 2010; Kharode, Sharp e Bodine, 2008; Robichaud et al., 2008). Para a realização deste estudo foram utilizadas ratas Wistar induzidas à osteoporose a partir da remoção cirúrgica dos ovários. A ovariectomia 
em roedores é uma técnica bem estabelecida na literatura para obtenção de um modelo animal com osteoporose, com condições ósseas similares às mulheres na pós-menopausa (Giro et al., 2011; Govindarajan et al., 2013; Lelovas et al., 2008). De acordo com Kalu (1991), as características de perda de densidade óssea em ratas ovariectomizadas são semelhantes às condições encontradas em mulheres na pós-menopausa.

Neste trabalho o tempo de espera entre a cirurgia e o sacrifício dos animais foi de 150 dias, prazo confiável para estabelecimento da osteoporose; no entanto este período pode variar dependendo do local alvo do estudo. Wronski, Dann e Horner (1989) realizaram experimentos com tempo de espera de 0 a 540 dias após a ovariectomia das ratas, avaliando a qualidade óssea de vértebras lombares e tíbias e notaram que uma significativa perda de volume ósseo na tíbia (cerca de $50 \%$ ) ocorreu entre 30 e 60 dias, enquanto que a mesma perda de volume para as vértebras se deu a partir de 270 dias, mostrando que há uma diferença na taxa de perda óssea entre distintos locais ao longo do tempo. Atmaca, Aydin e Musaoğlu (2013) avaliaram o efeito da ovariectomia nos ossos femurais e observaram que na 14ํㅡㄹ semana após a cirurgia a densidade mineral óssea era significativamente menor quando comparado ao grupo controle.

Passado o tempo de espera e realizadas as culturas celulares, iniciaram-se os ensaios de proliferação e viabilidade celular. Em estudo realizado por Yu et al. (2012) a proliferação e diferenciação de células osteoblásticas removidas da mandíbula de ratas osteoporóticas foram avaliadas, sendo observado um aumento dessas taxas no grupo ovariectomizado quando comparado ao grupo controle. Esse resultado também foi observado no presente estudo. Embora as células da calvária e medula óssea tenham sido plaqueadas na mesma densidade e cultivadas no 
mesmo ambiente, elas apresentaram comportamento diferentes. Enquanto as células diferenciadas da medula apresentaram maiores taxas de proliferação no grupo com osteoporose, na calvária pode-se notar um aumento na proliferação e viabilidade das células do grupo controle aos 7 e 10 dias de cultura.

Uma possível explicação é que as células mesenquimais da medula óssea estão localizadas em um ambiente específico e o estrógeno é um dos fatores que modula a proliferação celular (Zhang et al., 2011). Assim, sugere-se que na falta do hormônio as células tenderiam a se multiplicar a fim de buscar um equilíbrio no meio em que se encontram, o que não significa que o mesmo será estabelecido, uma vez que a diferenciação destas células é atrasada em relação às células obtidas da calvária.

Rosales-Rocabado et al. (2014) realizaram um estudo comparando o comportamento entre células da medula óssea e calvária em ratos sem osteoporose e observaram que, em uma situação normal, as células da calvária tem maior proliferação e viabilidade que as células da medula, apoiando a hipótese de que a osteoporose interfere no funcionamento celular. As células da calvária, incluindo as pertencentes ao grupo com osteoporose, apresentam maior diferenciação em relação à medula, e assim, sofrem mais com a remodelação óssea, ou seja, há um prejuízo em relação à multiplicação celular, uma vez que elas não tem a mesma capacidade de proliferação das células mesenquimais; dessa forma, os resultados no grupo ovariectomizado são menores quando comparado ao controle.

Quando avaliada a atividade de fosfatase alcalina (ALP), no primeiro período estudado não foi observada atividade desta enzima em nenhum dos grupos celulares. Já aos 10 e 14 dias notou-se um comportamento inverso entre os diferentes grupos. Enquanto um aumento da atividade de fosfatase se deu no grupo 
controle da calvária, outro aumento foi observado nas células do grupo com osteoporose da medula óssea, sendo que esta obteve um pico na atividade aos 14 dias de estudo. Shin et al. (2012) avaliaram os níveis séricos de ALP em ratas Sprague-Dawley após 4 e 8 semanas de ovariectomia e os níveis obtidos no grupo com osteoporose foram maiores que o grupo controle em ambos os períodos, visto que na $8^{a}$ semana a ALP apresentou valores mais altos em relação a $4^{a}$ semana. Essa atividade elevada de ALP nos animais ovariectomizados pode estar relacionada ao aumento do turnover ósseo, ou seja, da frequência de ativação do processo de remodelação óssea (Egrise et al., 1992; .Lumachi et al., 2009).

No ensaio de quantificação de nódulos de mineralização, calvária e medula apresentaram resultados distintos. Enquanto que as células da calvária foram condizentes com a hipótese de que o grupo controle apresentaria maior quantificação que o grupo com osteoporose, células da medula apresentaram resultados contrários e maior mineralização foi observada nas células do grupo de células de ratas com osteoporose. Em um estudo com células osteoblásticas de linhagem MC3T3-E1, Brennan et al. (2014), observaram maior atividade de ALP e mineralização no grupo controle quando comparado ao grupo com ausência de estrógeno, o que condiz com os resultados obtidos no grupo de células provenientes da calvária. Estes resultados se devem ao fato de que a falta de estrógeno interfere na proliferação e diferenciação dos osteoblastos e, assim, reduz a formação óssea.

A literatura apresenta dados conflitantes quanto a mineralização nas células de origem medular. Alguns estudos mostram declínio na mineralização em grupos osteoporóticos (Cheng et al. 2009), enquanto outros apontam um aumento nessa taxa (Busse et al. 2009). A análise quantitativa e qualitativa no presente estudo mostrou que as células da cálvaria em ratas ovariectomizadas formaram menos 
nódulos mineralizados quando comparado ao grupo controle; já as células provenientes da medula óssea de ratas ovariectomizadas formaram mais nódulos do que o grupo controle, principalmente aos 21 dias de cultura. Este comportamento pode estar associado à atividade de fosfatase alcalina, cujo papel como marcador da atividade osteogênica se encontra bem estabelecido (Golub e Boesze-Battaglia, 2007). Como já descrito anteriormente, a atividade desta enzima foi menor no grupo CO quando comparado ao grupo CC; inversamente, a atividade de ALP foi menor no grupo MC em relação ao grupo $\mathrm{MO}$.

Alterações no metabolismo celular podem ser avaliados por meio de análise de expressão gênica (PCR) de marcadores ósseos, que estão relacionados à formação ou reabsorção de tecidos mineralizados e alguns deles, associados à diferenciação celular.

Os resultados de Runx2, osteocalcina e fosfatase alcalina (Alpl) mostraram um padrão, visto que a expressão destes genes nas células do grupo com osteoporose foi maior que no grupo controle, o que não ocorreu com as células da calvária, onde estes genes mostraram maior expressão no grupo controle.

O gene Runx2 codifica uma proteína da família dos fatores de transcrição, estando relacionada à diferenciação osteoblástica e morfogênese do esqueleto. No presente trabalho, foi observado um aumento na expressão quantitativa do Runx2 nas células osteoblásticas de ratas ovariectomizadas. Este resultado também foi encontrado por Benisch et al. (2012), que observaram profundas mudanças no transcriptoma de células provenientes da medula óssea humana de pacientes com osteoporose. Entre estas mudanças, observaram um aumento na expressão de mRNA de genes associados à osteoporose, como o Runx2, Col1a1, além de genes envolvidos com a osteoclastogênese (Csf1, Pthr1). A modulação destes genes 
indica deficiências intrínsecas na diferenciação e autorrenovação celular na situação de osteoporose. Além disso, Merciris et al.(2007) mostraram em um estudo que a sobre-expressão de Runx2 afeta a diferenciação osteoblástica e induz a perda óssea em camundongos, podendo explicar os resultados da expressão deste gene para as células da medula óssea com osteoporose obtidos neste estudo.

Outro marcador importante no estudo da osteogênese é a osteocalcina, uma proteína não colágena encontrada em ossos e dentina, secretada por células osteoblásticas e que desempenha um papel essencial na regulação do metabolismo ósseo, estando relacionada à mineralização óssea e homeostase dos íons cálcio. Estas características se devem aos três ácidos glutâmicos presentes em sua estrutura que Ihe conferem a capacidade de ligar-se ao cálcio, participando desses processos (Lee et al., 2007). Nos resultados obtidos neste trabalho, esse gene precisou de muitos ciclos para ser expresso, estando fora da média obtida com outros marcadores. Merciris et al. (2007) também observaram esse resultado em seu estudo, relatando que este fato refere-se à baixa diferenciação osteoblástica, o que dificulta a mineralização de matriz osteóide, reduzindo a expressão desse gene. Maruotti et al. (2009) também demonstrou que em condições de osteoporose, os osteoblastos tem menor taxa de proliferação e suas funções são modificadas, ou seja, eles produzem quantidades menores de osteocalcina comparada às células normais.

Em casos de osteoporose, a relação entre os genes Rank-I e osteoprotegerina (Opg) são importantes para a análise entre formação e reabsorção óssea. Rank-I, receptor activator of nuclear factor kappa-B ligand, é uma proteína fundamental para o metabolismo ósseo adequado e está ligada à superfície de células osteoblásticas, agindo como um fator chave para ativação e diferenciação 
dos osteoclastos. A superprodução de Rank-I está ligada à presença de doenças ósseas degenerativas (Yasuda, 2013). Já a Opg, proteína solúvel sintetizada pelos osteoblastos, age como um receptor competitivo ligando-se ao Rank-I e impedindo sua ligação ao Rank, diminuindo a ação dos osteoclastos, uma vez que ela age inibindo a diferenciação de células pré-osteoclásticas em osteoclastos maduros.

Distúrbios na relação de Rank-I e osteoprotegerina são encontrados quando há deficiência de estrógeno (McClung, 2007). Nos resultados obtidos, foi possível notar que Rank-I e Opg foram expressos, entretanto, houve maior expressão de Rank-I, tal como notado por Rude et al. (2005). Tal fato pode ser explicado levando em consideração o baixo nível de estrógeno nos animais utilizados na pesquisa. Essa deficiência gera um desequilíbrio no metabolismo ósseo e aumenta a produção de citocinas pró-inflamatórias, tais como interleucina 1 (IL-1), interleucina 6 (IL-6) e fator de necrose tumoral alfa (TNF- $\alpha$ ) (Cheng et al., 2013). A IL-6 facilita a proliferação de precursores de osteoclastos, enquanto que a IL-1 e TNF- $\alpha$ melhoram a função dos osteoclastos. Para que essa cascata ocorra, tais células precisam ser ativadas, sendo o Rank-I o responsável por essa função, daí o aumento em sua expressão nas células osteoblásticas.

O estrógeno age no organismo por meio de dois receptores nucleares, o receptor de estrógeno alfa (Era) e o receptor de estrógeno beta $(\operatorname{Er} \beta)$. Ambos trabalham de forma similar e são conhecidos tanto por estimular os efeitos clássicos (genômicos) atuando como fatores de transcrição como pelos efeitos não-clássicos (não-genômicos), ativando distintas cascatas de proteína quinase citoplasmática (Sapir-Koren e Livshits, 2013). Este hormônio é importante no desenvolvimento e maturação óssea tanto em humanos como em animais por apresentar uma capacidade protetora frente às citocinas osteoclásticas (IL-1, IL-6 e TNF- $\alpha$ ) e, assim, 
inibir a reabsorção óssea exagerada (Krum e Brown, 2008). No entanto, este efeito protetor é perdido a partir da menopausa. Não é bem definido, na literatura, o funcionamento desses receptores, porém, o Era está associado à regulação de células formadoras de osso, tais como a resposta de osteoblastos frente a estímulos mecânicos. Sabe-se ainda que, quando co-expressos, o Erß possui função inibitória sobre a expressão de Era (Määttä et al., 2013). Neste experimento observou-se que, enquanto células da medula óssea de ambos os grupos (controle e osteoporótico) apresentaram maior expressão de Era, as células obtidas da calvária apresentaram maior expressão de Erß, assim, o local de origem celular ou sua diferenciação podem estar relacionados ao tipo de receptor de estrógeno, podendo ser mais ou menos expressos.

Sabe-se que o estrógeno regula a densidade óssea agindo por meio de uma variedade de mecanismos. Este hormônio age tanto de forma osteoblástica como anti-osteoclástica, atuando na manutenção óssea. Entretanto, uma questão não respondida é quais os papéis dos receptores de estrógeno (Era e $\operatorname{Er} \beta)$ em cada tipo de célula, principalmente, células mesenquimais e osteoblastos. 
Ponclusiñ 


\section{CONCLUSÃO}

Diante dos resultados obtidos, pode ser concluído por meio dos ensaios bioquímicos que existem diferenças metabólicas entre as células da calvária e as células da medula óssea de ratas ovariectomizadas quando comparado ao grupo de ratas controle. Esses resultados também mostram um padrão de expressão gênica distinta e sugerem que as células da medula óssea sofrem um ajuste metabólico com a intenção de compensar os efeitos da diminuição do estrógeno neste modelo de osteoporose. 
Qeferénciass \$ibliográficas 


\section{REFERÊNCIAS BIBLIOGRÁFICAS}

ALBRIGHT F, BLOOMBERG E, SMITH PH. Postmenopausal osteoporosis. Trans. Assoc. Am. Physicians 1940 55: 298-305.

AMADEI SU, SILVEIRA VAS, PEREIRA AC, CARVALHO YR, ROCHA RF. Effect of estrogen deficiency on bone turnover and bone repair. J. Bras. Pato. Med. Lab. 2006 42(1): 5-12.

ATMACA H, AYDIN A, MUSAOĞLU R. Experimental model of osteoporosis: comparison between ovariectomy and botulinum toxin a. Acta Ortop. Bras. 2013 21(6): 340-343.

BECKER C. Pathophysiology and clinical manifestations of osteoporosis. Clin. Cornestone. 2008 9(2): 42-47.

BENISCH P, SCHILLING T, KLEIN-HITPASS L, FREY SP, SEEFRIED L, RAAIJMAKERS N, KRUG M, REGENSBURGER M, ZECK S, SCHINKE T, AMLING M, EBERT R, JAKOB F. The transcriptional profile of mesenchymal stem cell populations in primary osteoporosis is distinct and shows overexpression of osteogenic inhibitors. Plos One. 2012 7(9): 1-13.

BRANDÃO CM, FERRÉ F, MACHADO GP, GUERRA JR AA, ANDRADE El, CHERCHIGLIA ML, ACURCIO FA. Public spending on drugs for the treatment of osteoporosis in post-menopause. Rev. Saúde Pública. 2013 47(2): 390-402. 
BRENNAN MA, HAUGH MG, O'BRIEN FJ, MCNAMARA LM. Estrogen withdrawal from osteoblasts and osteocytes causes increased mineralization and apoptosis. Horm. Metab. Res. 2014 [in press].

BUSSE B, HAHN M, SOLTAU M, ZUSTIN J, PUSCHEL K, DUDA GN, AMLING M. Increased calcium content and inhomogeneity of mineralization render bone toughness in osteoporosis: mineralization, morphology and biomechanics of human single trabeculae. Bone. 2009 45(6): 1034-1043.

CHENG BH, WANG TH, KANG HY, LIN YC, HUANG CC, HSU TY, KUNG FT, HUANG KE. Association between single nucleotide polymorphisms of the estrogen receptor 1 and receptor activator of nuclear factor kappa B ligand genes and bone mineral density in postmenopausal Taiwanese. Taiwan J. Obstet. Gynecol. 2013 52(2): 197-203.

CHENG Z, YAO W, ZIMMERMANN EA, BUSSE C, RITCHIE RO, LANE NE. Prolonged treatments with antiresorptive agents and PTH have different effects on bone strength and the degree of mineralization in old estrogen-deficient osteoporotic rats. J. Bone Miner. Res. 2009 24(2): 209-22.

DALLANEZI G, NAHAS EA, FREIRE BF, NAHAS-NETO J, CORRENTE JE, MAZETO GM. Quality of life of women with low bone mass in postmenopause. Rev. Bras. Ginecol. Obstet. 2011 33(3): 133-138. 
D'AMELIO P, ROATO I, D'AMICO L, VENEZIANO L, SUMAN E. Bone and bone marrow pro-osteoclastogenic cytokines are up-regulated in osteoporosis fragility fractures. Osteoporosis International. 2011 22(11): 2869-2877.

DEMPSTER DW, LAMBING CL, KOSTENUIK PJ, GRAUER A. Role of RANK ligand and denosumab, a targeted RANK ligand inhibitor, in bone health and osteoporosis: a review of preclinical and clinical data. Clin. Therapeutics. 2012 34(3): 521-36.

DOWNEY P, SIEGEL MI. Bone biology and the clinical implications for osteoporosis. Phys. Therapy. 2006 86(1): 77-91.

DUNCAN EL, BROWN MA. Mapping genes for osteoporosis - old dogs and new tricks. Bone. 2010 46(5): 1219-1225.

EGRISE D, MARTIN D, NEVE P, VIENNE A, VERHAS M, SCHOUTENS A. Bone blood flow and in vitro proliferation of bone marrow and trabecular bone osteoblastlike cells in ovariectomized rats. Calcif. Tissue Int.1992 50(4): 336-341.

FROST HM, JEE WSS. On the rat model of human osteopenias and osteoporoses. Bone Mineral. 1992 18(3): 227-236.

GIRO G, COELHO PG, SALES-PESSOA R, PEREIRA RM, KAWAI T, ORRICO SR. Influence of estrogen deficiency on bone around osseointegrated dental implants: an experimental study in the rat jaw model. J. Oral Maxillofac. Surg. 2011 69(7): 19111918. 
GOLUB EE, BOESZE-BATTAGLIA K. The role of alkaline phosphatase in mineralization. Cur. Opin. Orthop. 2007 18(5): 444-448.

GOVINDARAJAN P, BÖCKER W, EL KHASSAWNA T, KAMPSCHULTE M, SCHLEWITZ G, HUERTER B, SOMMER U, DÜRSELEN L, IGNATIUS A, BAUER N, SZALAY G,WENISCH S, LIPS KS, SCHNETTLER R, LANGHEINRICH A, HEISS C. Bone matrix, cellularity, and structural changes ina rat model withhighturnoverosteoporosis induced by combined ovariectomy and a multiple-deficient diet. Am. J. Pathol. 2013 184(3): 765-777.

GREGORY CA, GUNN WG, PEISTER A, PROCKOP DJ. An Alizarin red-based assay of mineralization by adherent cells in culture: comparison with cetylpyridinium chloride extraction. Anal Biochemicals. 2004 329(1): 77-84.

HOAR W, HICKMAN CP. Ovariectomy and the estrous cycle of the rat. In: W Hoar \& CP Hickman, editors. General and comparative physiology. $2^{a}$ ed. New Jersey: Prentice-hall; 1975. p. 265.

HOROWITZ, MC. Cytokines and estrogen in bone: anti-osteoporotic effects. Science. 1993 260(5108): 626-627.

KALU DN. The ovariectomized rat model of postmenopausal bone loss. Bone Mineral. 1991 15(3): 171-192. 
KHARODE YP, SHARP MC, BODINE PV. Utility of the ovariectomized rat as a model for human osteoporosis in drug discovery. Methods Mol. Biol. 2008 455: 111 124.

KRUM SA, BROWN M. Unraveling estrogen action in osteoporosis. Cell Cycle. 2008 7(10): 1348-1352.

LEE NK, SOWA H, HINOI E, FERRON M, AHN JD, CONFAVREUX C, DACQUIN R, MEE PJ, MCKEE MD, JUNG DY, ZHANG Z, KIM JK, MAUVAIS-JARVIS F, DUCY P, KARSENTY G. Endocrine regulation of energy by metabolism by the skeleton. Cell. 2007 130(3): 456-469.

LELOVAS PP, XANTHOS TT, THOMA SE, LYRITIS GP, DONTAS IA. The laboratory rat as an animal model for osteoporosis research. Comp. Med. 2008 58(5): 424-430. LI N, JIANG Y, WOOLEY PH, XU Z, YANG SY. Naringin promotes osteoblast differentiation and effectively reverses ovariectomy-associated osteoporosis. J. Orthop. Sci. 2013 18(3): 478-485.

LIVAK KJ, SCHMITTGEN TD. Analysis of relative gene expression data using realtime quantitative PCR and the 2(-Delta Delta C(T)) method. Methods. 2001 25(4): 402-408.

LOWRY OH, ROSEBROUGH NJ, FARR AL, RANDALL RJ. Protein measurement with the Folin phenol reagent. J. Biol. Chemical. 1951 193(1): 265-275. 
LUMACHI F, ERMANI M, CAMOZZI V, TOMBOLAN V, LUISETTO G. Changes of bone formation markers osteocalcin and bone-specific alkaline phosphatase in postmenopausal women with osteoporosis. Ann. N. Y. Acad. Sci. 2009 1173(1): E6063.

MÄÄTTÄ JA, BÜKI KG, GU G, ALANNE MH, VÄÄRÄNIEMI J, LILJENBÄCK H, POUTANEN M, HÄRKÖNEN P, VÄÄNÄNEN K. Inactivation of estrogen receptor $\alpha$ in bone-forming cells induces bone loss in female mice. Faseb J. 2013 27(2): 478488.

MAILHOT JM, BORKE JL. An isolation and in vitro culturing method for human intraoral bone cells derived from dental implant preparation sites. Clin. Oral Implants Research. 1998 9: 43-50.

MANIATOPOULOS C, SODEK J, MELCHER AH. Bone formation in vitro by stromal cells obtained from bone marrow of young adult rats. Cell Tissue Research. 1988 254: 317-330.

MANOLAGAS SC, JILKA RL. Bone marrow, cytokines, and bone remodeling. Emerging insights into the pathophysiology of osteoporosis. N. Engl. J. Medicine. $1995332(5): 305-311$.

MARCONDES FK, BIANCHI FJ, TANNO AP. Determination of the estrous cycle phases of rats: Some helpful considerations. Braz. J. Biology. 2002 62(4): 609-614. 
MARIE PJ, KASSEM M. Osteoblasts in osteoporosis: past, emerging, and future anabolic targets. Eur. J. Endocrinology. 2011 165(1): 1-10.

MARUOTTI N, CORRADO A, GRANO M, COLUCCI S, CANTATORE FP. Normal and osteoporotic human osteoblast behaviour after 1,25-dihydroxy-vitamin(D3) stimulation. Rheumatol. Int. 2009 29(6): 667-672.

MARUOTTI N, CORRADO A, NEVE A, CANTATORE FP. Bisphosphonates: effects on osteoblast. Eur. J. Clin. Pharmacology. 2012 68(7): 1013-1018.

McCLUNG M. Role of RANKL inhibition in osteoporosis. Arthritis Res. Ther. 20079 (Suppl 1): S3-S8.

MERCIRIS D, MARTY C, COLLET C, DE VERNEJOUL MC, GEOFFROY V. Overexpression of the transcriptional factor runx2 in osteoblasts abolishes the anabolic effect of parathyroid hormone in vivo. Am. J. Pathol. 2007 170(5): 16761685.

OLIVEIRA LG. Osteoporose: guia para diagnóstico, prevenção e tratamento. 1ำ ed. Rio de Janeiro: Revinter; 2002. p. 431.

PACIFICI R. Estrogen, cytokines, and pathogenesis of postmenopausal osteoporosis. J. Bone Miner. Research. 1996 11(8): 1043-1051.

RAISZ LG. Pathogenesis of osteoporosis: concepts, conflicts and prospects. J. Clin. 
Investigation. 2005 115(12): 3318-3325.

RAWLINSON SCF, BOYDE A, DAVIS GR, HOWELL PGT, HUGHES FJ, KINGSMILL VJ. Ovariectomy vs. hypofunction: Their effects on rat mandibular bone. J. Dent. Research. 2009 88(7): 615-620.

ROBICHAUD J, BLACK WC, THÉRIEN M, PAQUET J, OBALLA RM, BAYLY CI, MCKAY DJ, WANG Q, ISABEL E, LÉGER S, MELLON C, KIMMEL DB, WESOLOWSKI G, PERCIVAL MD,MASSÉ F, DESMARAIS S, FALGUEYRET JP, CRANE SN. Identification of a nonbasic, nitrile-containing cathepsin $\mathrm{K}$ inhibitor (MK-1256) that is efficacious in a monkeymodel of osteoporosis. J. Med. Chem. 2008 51(20): 6410-6420.

ROSALES-ROCABADO JM, KAKU M, KITAMI M, AKIBA Y, UOSHIMA K. Osteoblastic differentiation and mineralization ability of periosteum derived cells compared with bone marrow andcalvaria-derived cells. J. Oral Maxillofac. Surg. 2014 72(4): 694.e1-9.

RUDE RK, GRUBER HE, WEI LY, FRAUSTO A. Immunolocalization of RANKL is increased and OPG decreased during dietary magnesium deficiency in the rat. Nutr. Metab. 2005 2(1): 24-31.

RUIZ-GASPÀ S, BLANCH-RUBIÓ J, CIRIA-RECASENS M, MONFORT J, TÍO L, GARCIA-GIRALT N, NOGUÉS X, MONLLAU JC, CARBONELL-ABELLÓ J, PÉREZ-EDO L. Reduced proliferation and osteocalcin expression in osteoblasts 
of male idiopathic osteoporosis. Calcif. Tissue Int. 2010 86(3): 220-226.

SANDHU SK, HAMPSON G. The pathogenesis, diagnosis, investigation and management of osteoporosis. J. Clin. Pathology. 2011 64(12): 1042-1050.

SAPIR-KOREN S, LIVSHITS G. Is interaction between age-dependent decline in mechanical stimulation and osteocyte-estrogen receptor levels the culprit for postmenopausal-impaired bone formation? Osteoporosis International. 2013 24: $1771-1789$.

SHIN YH, CHO DC, YU SH, KIM KT, CHO HJ, SUNG JK. Histomorphometric analysis of the spine and femur in ovariectomized rats using micro-computed tomographic scan. J. Korean Neurosurg. Soc. 2012 52(1): 1-6.

SIMON LS. Osteoporosis. Rheum. Dis. Clin. North America. 2007 33(1): 149-176.

SIMONET WS, LACEY DL, DUNSTAN CR. Osteoprotegerin: a novel secreted protein involved in the regulation of bone density. Cell. 1997 89: 309-319.

TURNER RT, MARAN A, LOTINUN S, HEFFERAN T, EVANS GL, ZHANG M, SIBONGA JD. Animal models for osteoporosis. Rev. Endocr. Metab. Disord. 2001 2(1): 117-27.

VERONESI F, TORRICELLI P, BORSARI V, TSCHON M, RIMONDINI L, FINI M. Mesenchymal stem cells in the aging and osteoporotic population. Crit. Rev. 
Eukaryot. Gene Expression. 2011 21(4): 363-377.

WRONSKI TJ, SOWRY PL, WALSH CC, IGNASZEWSKI LA. Skeletal alterations in ovariectomized rats. Calcif. Tissue International. 1985 37: 324-328.

WRONSKI TJ, DANN LM, HORNER SL. Time course of vertebral osteopenia in ovariectomized rats. Bone. 1989 10(4): 295-301.

YASUDA H. Rankl, a necessary chance for clinical application to osteoporosis and cancer-related bone diseases. World J. Orthop. 2013 4(4): 207-217.

YU SJ, LIU HC, LING-LING E, WANG DS, ZHU GX. Proliferation and differentiation of osteoblasts from the mandible of osteoporotic rats. Exp. Biol. Med. 2012 237(4): 395406.

ZHANG B, LI Y, ZHOU Q, DING Y. Estrogen deficiency leads to impaired osteogenic differentiation of periodontal ligament stem cell in rats. Tohoku J. Exp. Med. 2011 223(3):177-186. 
Apênatice 


\section{APÊNDICE}

APÊNDICE A - Tabelas estatísticas com valores de $p$ dos experimentos de proliferação e viabilidade celular.

\begin{tabular}{|c|c|c|c|}
\hline \multicolumn{4}{|c|}{ Proliferação celular } \\
\hline & & Kruskal Wallis & Mann Whitney \\
\hline \multirow{4}{*}{$\begin{array}{l}\frac{\pi}{\pi} \\
\frac{\pi}{0} \\
m\end{array}$} & $\mathrm{MC} \times \mathrm{MO}$ & \multirow{4}{*}{0,000} & 0,000 \\
\hline & $\mathrm{CC} \times \mathrm{CO}$ & & 0,908 \\
\hline & $\mathrm{MC} \times \mathrm{CC}$ & & 0,012 \\
\hline & $\mathrm{MO} \times \mathrm{CO}$ & & 0,000 \\
\hline \multirow{4}{*}{$\begin{array}{l}\frac{\pi}{\pi} \\
\frac{\pi}{0} \\
1\end{array}$} & $\mathrm{MC} \times \mathrm{MO}$ & \multirow{4}{*}{0,000} & 0,325 \\
\hline & $\mathrm{CC} \times \mathrm{CO}$ & & 0,000 \\
\hline & $\mathrm{MC} \times \mathrm{CC}$ & & 0,000 \\
\hline & $\mathrm{MO} \times \mathrm{CO}$ & & 0,001 \\
\hline \multirow{4}{*}{$\begin{array}{l}\mathscr{\infty} \\
: \frac{\pi}{0} \\
0 \\
\end{array}$} & $\mathrm{MC} \times \mathrm{MO}$ & \multirow{4}{*}{0,000} & 0,000 \\
\hline & $\mathrm{CC} \times \mathrm{CO}$ & & 0,000 \\
\hline & $M C \times C C$ & & 0,000 \\
\hline & $\mathrm{MO} \times \mathrm{CO}$ & & 0,000 \\
\hline
\end{tabular}

\begin{tabular}{|c|c|c|c|}
\hline \multicolumn{4}{|c|}{ Viabilidade celular (MTT) } \\
\hline & & Kruskal Wallis & Mann Whitney \\
\hline \multirow{4}{*}{ 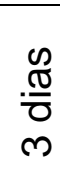 } & $\mathrm{MC} \times \mathrm{MO}$ & \multirow{4}{*}{0,001} & 0,009 \\
\hline & $\mathrm{CC} \times \mathrm{CO}$ & & 0,028 \\
\hline & $\mathrm{MC} \times \mathrm{CC}$ & & 0,009 \\
\hline & $\mathrm{MO} \times \mathrm{CO}$ & & 0,009 \\
\hline \multirow{4}{*}{$\begin{array}{l}\mathbb{\mathscr { T }} \\
\frac{\mathbb{O}}{0} \\
N\end{array}$} & $\mathrm{MC} \times \mathrm{MO}$ & \multirow{4}{*}{0,001} & 0,009 \\
\hline & $\mathrm{CC} \times \mathrm{CO}$ & & 0,009 \\
\hline & $M C \times C C$ & & 0,009 \\
\hline & $\mathrm{MO} \times \mathrm{CO}$ & & 0,016 \\
\hline \multirow{4}{*}{$\begin{array}{l}\mathbb{D} \\
: \frac{\pi}{0} \\
\text { O }\end{array}$} & $\mathrm{MC} \times \mathrm{MO}$ & \multirow{4}{*}{0,001} & 0,530 \\
\hline & $\mathrm{CC} \times \mathrm{CO}$ & & 0,009 \\
\hline & $\mathrm{MC} \times \mathrm{CC}$ & & 0,009 \\
\hline & $\mathrm{MO} \times \mathrm{CO}$ & & 0,009 \\
\hline
\end{tabular}


APÊNDICE B - Tabelas estatísticas com valores de $p$ da atividade de fosfatase alcalina e quantificação de nódulos de mineralização.

\begin{tabular}{|c|c|c|c|}
\hline \multicolumn{4}{|c|}{ Atividade de fosfatase alcalina (ALP) } \\
\hline & & Kruskal Wallis & Mann Whitney \\
\hline \multirow{4}{*}{$\begin{array}{l}\frac{\pi}{0} \\
\frac{\pi}{0} \\
N\end{array}$} & $\mathrm{MC} \times \mathrm{MO}$ & \multirow{4}{*}{0,162} & 0,290 \\
\hline & $\mathrm{CC} \times \mathrm{CO}$ & & 0.317 \\
\hline & $\mathrm{MC} \times \mathrm{CC}$ & & 0,881 \\
\hline & $\mathrm{MO} \times \mathrm{CO}$ & & 0,054 \\
\hline \multirow{4}{*}{$\begin{array}{l}\frac{\pi}{0} \\
\frac{\pi}{0} \\
0\end{array}$} & $\mathrm{MC} \times \mathrm{MO}$ & \multirow{4}{*}{0,002} & 0,009 \\
\hline & $\mathrm{CC} \times \mathrm{CO}$ & & 0,009 \\
\hline & $\mathrm{MC} \times \mathrm{CC}$ & & 0,009 \\
\hline & $\mathrm{MO} \times \mathrm{CO}$ & & 0,009 \\
\hline \multirow{4}{*}{  } & $\mathrm{MC} \times \mathrm{MO}$ & \multirow{4}{*}{0,000} & 0,009 \\
\hline & $\mathrm{CC} \times \mathrm{CO}$ & & 0,009 \\
\hline & $\mathrm{MC} \times \mathrm{CC}$ & & 0,009 \\
\hline & $\mathrm{MO} \times \mathrm{CO}$ & & 0,009 \\
\hline
\end{tabular}

\begin{tabular}{|c|c|c|c|}
\hline \multicolumn{4}{|c|}{ Quantificação de nódulos de mineralização } \\
\hline & & Kruskal Wallis & Mann Whitney \\
\hline \multirow{4}{*}{$\begin{array}{l}\mathbb{0} \\
\frac{\mathbb{\sigma}}{0} \\
\stackrel{+}{-}\end{array}$} & $\mathrm{MC} \times \mathrm{MO}$ & \multirow{4}{*}{0,022} & 0,075 \\
\hline & $\mathrm{CC} \times \mathrm{CO}$ & & 0,009 \\
\hline & $\mathrm{MC} \times \mathrm{CC}$ & & 0,115 \\
\hline & $\mathrm{MO} \times \mathrm{CO}$ & & 0,009 \\
\hline \multirow{4}{*}{$\begin{array}{l}\frac{\pi}{\pi} \\
\frac{\pi}{0} \\
\frac{\sim}{N}\end{array}$} & $\mathrm{MC} \times \mathrm{MO}$ & \multirow{4}{*}{0,009} & 0,076 \\
\hline & $\mathrm{CC} \times \mathrm{CO}$ & & 0,009 \\
\hline & $\mathrm{MC} \times \mathrm{CC}$ & & 0,116 \\
\hline & $\mathrm{MO} \times \mathrm{CO}$ & & 0,009 \\
\hline
\end{tabular}


APÊNDICE C - Tabelas estatísticas com valores de $p$ da análise da expressão gênica por meio de Real-time PCR.

\begin{tabular}{c|c|c|c|c|c|c|c|c}
\hline \multicolumn{1}{c}{ KRUSKAL WALLIS } \\
\hline & Runx2 & Alpl & Era & Er $\beta$ & Oc & Rank-I & Opg & Rank-I/Opg \\
\hline $\begin{array}{c}\text { Grupos 1 a 4 } \\
\text { MC3d, MO3d } \\
\text { CC3d, CO3d }\end{array}$ & 0,005 & 0,005 & 0,018 & 0,005 & 0,033 & 0,007 & 0,024 & 0,028 \\
\hline $\begin{array}{c}\text { Grupos 5 a 8 } \\
\text { MC7d, MO7d } \\
\text { CC7d, C07d }\end{array}$ & 0,003 & 0,004 & 0,006 & 0,003 & 0,004 & 0,003 & 0,004 & 0,003 \\
\hline $\begin{array}{c}\text { Grupos 9 a 12 } \\
\text { MC10d, MO10d } \\
\text { CC10d, C010d }\end{array}$ & 0,003 & 0,003 & 0,008 & 0,002 & 0,003 & 0,004 & 0,003 & 0,003 \\
\hline
\end{tabular}

\section{MANN WHITNEY}

\begin{tabular}{l|c|c|c|c|c|c|c|c}
\hline & Runx2 & Alpl & Era & Er $\beta$ & Oc & Rank-I & Opg & Rank-I/Opg \\
\hline MC3d x MO3d & 0,021 & 0,021 & 0,149 & 0,021 & 0,564 & 0,043 & 0,021 & 0,773 \\
CC3d x CO3d & 0,021 & 0,020 & 0,021 & 0,021 & 0,021 & 0,021 & 0,149 & 0,021 \\
MC3d x CC3d & 0,773 & 0,773 & 1,000 & 1,000 & 1,000 & 1,000 & 0,773 & 0,663 \\
MO3d x CO3d & 0,021 & 0,020 & 0,021 & 0,021 & 0,021 & 0,021 & 0,021 & 0,021 \\
\hline MC7d x MO7d & 0,021 & 0,021 & 0,021 & 0,020 & 0,021 & 0,021 & 0,021 & 0,021 \\
CC7d x CO7d & 0,021 & 0,020 & 0,149 & 0,021 & 0,020 & 0,021 & 0,021 & 0,021 \\
MC7d x CC7d & 0,021 & 0,149 & 0,110 & 0,020 & 0,021 & 0,021 & 0,021 & 0,021 \\
MO7d x CO7d & 0,021 & 0,020 & 0,021 & 0,021 & 0,020 & 0,021 & 0,021 & 0,021 \\
\hline MC10d x MO10d & 0,021 & 0,021 & 0,248 & 0,014 & 0,021 & 0,083 & 0,021 & 0,021 \\
CC10d x C010d & 0,021 & 0,021 & 0,021 & 0,021 & 0,021 & 0,021 & 0,021 & 0,021 \\
MC10d x CC10d & 0,021 & 0,021 & 0,083 & 0,014 & 0,021 & 0,021 & 0,021 & 0,021 \\
MO10d x C010d & 0,021 & 0,021 & 0,021 & 0,021 & 0,021 & 0,021 & 0,021 & 0,021 \\
\hline
\end{tabular}


Anexos 


\title{
ANEXOS
}

\section{ANEXO A - Certificado de aprovação da Comissão de Ética no Uso de Animais}

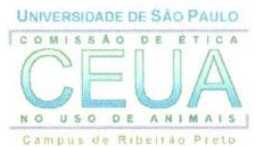

\author{
UNIVERSIDADE DE SÃO PAULO \\ Campus de Ribeirão Preto \\ Comissão de Ética no Uso de Animais
}

\section{E R T I F I C A D O}

Certificamos que o trabalho (Protocolo $n^{\circ}$ 12.1.1286.53.0), intitulado "Análise Comparativa in vitro do Efeito da Osteoporose no Comportamento de Células Osteoblásticas da Medula Óssea e da Calvária de Ratas Ovariectomizadas", de autoria de Fernanda Grilo de Azevedo e de Karina Fitipaldi Bombonato Prado, por estar de acordo com os Princípios Éticos na Experimentação Animal adotado pela Comissão de Ética no Uso de Animais (CEUA) do Campus de Ribeirão Preto - USP foi aprovado em reunião da CEUA de 05.11.2012.

This is to certify that the work (Protocol number 12.1.1286.53.0), entitled: "Anélise Comparativa in vitro do Efeito da Osteoporose no Comportamento de Células Osteoblásticas da Medula Óssea e da Calvária de Ratas Ovariectomizadas", by Fernanda Grilo de Azevedo and Karina Fitipladi Bombonato Prado, is in accordance with the Ethic Principles in Animal Experimentation adopted by Ethic Commission for the Use of Animals (CEUA) of the Campus of Ribeirão Preto - USP, and was approved in the meeting, November, 52012.

Ribeirão Preto, 21 de novembro de 2012

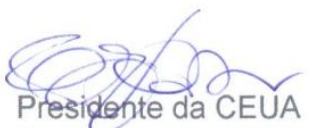

Profa.Dra. Claudia Maria Padovan



Mayia Angélica Depiro

Av. Bandeirantes, 3900 - CEP 14040-900 - Ribeirão Preto - São Paulo Fone: (16) 36024469 - Fax: (16) 36337964 